OPEN ACCESS

Implications of the Heat Generation of LMR-NCM on the Thermal Behavior of Large-Format Lithium-Ion Batteries

To cite this article: Ludwig Kraft et al 2021 J. Electrochem. Soc. 168053505

View the article online for updates and enhancements. 


\title{
Implications of the Heat Generation of LMR-NCM on the Thermal Behavior of Large-Format Lithium-Ion Batteries
}

\author{
Ludwig Kraft, ${ }^{1, *, z}$ (i) Alexander Hoefling, ${ }^{2,3}$ Tanja Zünd, ${ }^{4, *}$ (1) Alexander Kunz, ${ }^{1}$ (i) \\ Marco Steinhardt, ${ }^{1}$ (i) Jens Tübke, ${ }^{2,3}$ and Andreas Jossen ${ }^{1}$ (i) \\ ${ }^{1}$ Institute for Electrical Energy Storage Technology, Technical University of Munich (TUM), Munich, Germany \\ ${ }^{2}$ Helmholtz Institute Ulm (HIU), Ulm, Germany \\ ${ }^{3}$ Karlsruhe Institute of Technology (KIT), Karlsruhe, Germany \\ ${ }^{4}$ Chair of Technical Electrochemistry, Technical University of Munich (TUM), Garching, Germany
}

\begin{abstract}
Lithium- and manganese-rich NCM (LMR-NCM) cathode active materials exhibit a pronounced energy inefficiency during charge and discharge that results in a strong heat generation during operation. The implications of such a heat generation are investigated for large-format lithium-ion batteries. Small laboratory cells are generally considered isothermal, but for larger cell formats this heat cannot be neglected. Therefore, the heat generation of LMR-NCM/graphite coin cells and NCA/graphite coin cells as a reference is measured for varying charge/discharge rates in an isothermal heat flow calorimeter and scaled to larger standardized cell formats. With the aid of thermal 3D models, the temperature evolution within these cell formats under different charge/ discharge operations and cooling conditions is analyzed. Without an additional heat sink and any active cooling of larger LMR$\mathrm{NCM}$ /graphite cells, discharge C-rates lower than $\mathrm{C} / 2$ are advisable to keep the cell temperature below a critical threshold. If the loads are increased, the cooling strategy has to be adapted to the specific cell format, otherwise critical temperatures above $60^{\circ} \mathrm{C}$ are easily reached. For the investigated convective surface cooling and base plate cooling scenarios, thick prismatic cell formats with LMR-NCM are generally unfavorable, as the large amount of heat cannot be adequately dissipated.

(C) 2021 The Author(s). Published on behalf of The Electrochemical Society by IOP Publishing Limited. This is an open access article distributed under the terms of the Creative Commons Attribution 4.0 License (CC BY, http://creativecommons.org/licenses/ by/4.0/), which permits unrestricted reuse of the work in any medium, provided the original work is properly cited. [DOI: 10.1149/ 1945-7111/ac0069]
\end{abstract}

Manuscript submitted February 19, 2021; revised manuscript received April 27, 2021. Published May 27, 2021.

State-of-the-art electric vehicles (EVs) rely on lithium-ion batteries that come in different sizes and chemical compositions. The driving range and thereby the accompanying customer acceptance of EVs is highly dependent on the energy density of the used battery system. In order to increase the energy density, the latest trend goes toward larger cell formats and active materials with a higher specific capacity, ${ }^{1-4}$ whereas the thermal behavior of these cells, including the thermal management system that is necessary to keep an optimal operating range, is often neglected. ${ }^{5}$

There are three main designs of cell formats, namely cylindric, prismatic, and pouch. While most automobile manufacturers rely on either prismatic or pouch cells, Tesla poses an exception and uses cylindric cells in their EVs. ${ }^{3,4}$ Their early Tesla Model S in 2012 relied on 18650 cylindric cells, while the more recent Tesla Model 3 uses advanced 21700 cells. ${ }^{3,4}$ Reportedly, Tesla now manufactures even larger 46800 cells. $^{6}$ By changing the cell format from 18650 to 21700 , the cell volume increases, meaning that more active material can be packed into the cell, which results in an increased energy content of around $49 \%$ per cell and potentially lower production costs. ${ }^{7,8}$ A similar trend can be seen for prismatic and pouch cell formats used by automobile manufacturers, some of them are defined in the standard DIN 91252, ${ }^{9}$ which gives design specifications for lithium-ion battery cells. Within this standard, the geometric dimensions of prismatic and pouch cell formats for hybrid electric vehicles (HEVs), plug-in hybrid electric vehicles (PHEVs), and battery electric vehicles (BEVs) are defined. As an example, the prismatic format BEV4 features an increased volume of $53 \%$ in comparison to the older BEV1 format.

Besides larger cell formats, anode active materials (AAMs) and cathode active materials (CAMs) with higher specific capacities are used for automotive cells. Almost all automotive cells contain graphite AAMs with a theoretical specific capacity of $372 \mathrm{mAh} \mathrm{g}^{-1}$. Only a few use lithium-titanate (LTO), e.g., Honda in its 2013 Fit EV, ${ }^{3,410}$ with only $175 \mathrm{mAh} \mathrm{g}^{-1}$ at a comparably high potential of $\approx 1.55 \mathrm{~V} \mathrm{vs} \mathrm{Li}^{\prime} / \mathrm{Li}^{+} .{ }^{11,12}$ Pristine silicon offers a theoretical capacity of $4200 \mathrm{mAh} \mathrm{g}^{-1}$ that is accompanied by high volume changes up to $320 \% .^{12}$ By adding

*Electrochemical Society Student Member.

${ }^{\mathrm{z}}$ E-mail: ludwig.kraft@tum.de some silicon to graphite anodes, the specific capacity can be boosted, ${ }^{13-15}$ which is why cells with silicon-graphite ( $\left.\mathrm{Si}-\mathrm{C}\right)$ composite anodes are reportedly used in more recent EVs like the Tesla Model X or Model 3.,4

There is a variety of CAMs for automotive cells, ranging from layered lithium-nickel-cobalt-manganese-oxide (NCM, 160-200 $\mathrm{mAh} \mathrm{g}^{-1}$ ) and lithium-nickel-cobalt-aluminum-oxide (NCA, 180-200 $\mathrm{mAh} \mathrm{g}^{-1}$ ) to spinel lithium-manganese-oxide (LMO, 100-120 mAh g ${ }^{-1}$ ) to olivine lithium-iron-phosphate (LFP, $160-165 \mathrm{mAh} \mathrm{g}^{-1}$ ) or even a blend of two or more of these materials. $^{3,4,7,10}$ A CAM that offers a higher specific capacity of around $250 \mathrm{mAh} \mathrm{g}^{-110,16-19}$ is lithium- and manganese-rich NCM (LMR-NCM). LMR-NCM is environmentally benign and a low cost alternative to nickel-rich materials due to a high manganese content, ${ }^{18,20}$ but faces structural changes accompanied by voltage fading as well as a pronounced voltage hysteresis. ${ }^{18-23}$ The material LMR-NCM is in the focus of current research and it was shown that cells containing LMR-NCM can be cycled for several hundred cycles before they reach a state-of-health of $80 \% .^{18,19,24}$ Thereby, the capacity loss is not only related to structural changes of LMR-NCM, but also to electrolyte stability issues, as LMR-NCM is often cycled up to $4.7-4.8 \mathrm{~V}$ vs $\mathrm{Li} / \mathrm{Li}^{+} \cdot{ }^{18,21,24}$ Despite the remaining challenges, the high specific capacity combined with the lower material costs render LMRNCM to a promising CAM for future lithium-ion batteries. ${ }^{3,20,25}$

Meister et al. ${ }^{26}$ classified the energy efficiency of various CAMs and AAMs for a $1 \mathrm{C}$ charge/discharge cycle. In their study, LMRNCM $\left(0.5 \mathrm{Li}_{2} \mathrm{MnO}_{3} \cdot 0.5 \mathrm{LiNi}_{0.4} \mathrm{Co}_{0.2} \mathrm{Mn}_{0.4} \mathrm{O}_{2}\right)$ reached a $85 \%$ round-trip energy efficiency, for comparison, NCM-111 was classified with $96 \%$, NCA was not studied. Of the investigated AAMs, graphite reached the highest round-trip energy efficiency with $94 \%$. The Si-C composite (20 wt\% silicon, $60 \mathrm{wt} \%$ graphite, $10 \mathrm{wt} \%$ binder, $10 \mathrm{wt} \%$ carbon black) with a practical capacity of around $1100 \mathrm{mAh} \mathrm{g}^{-1}$ in the first cycles, reached a lower efficiency of $89 \%$. The energy inefficiency of the active material LMR-NCM, but also of the Si-C composite, was mainly caused by a lower voltage efficiency, which is defined as the ratio of the mean discharge voltage to the mean charge voltage in a full cycle. ${ }^{26}$

In our previous publication, multilayer LMR-NCM/graphite and $\mathrm{NCA} /$ graphite pouch cells with a nominal capacity of around 6-7 Ah 


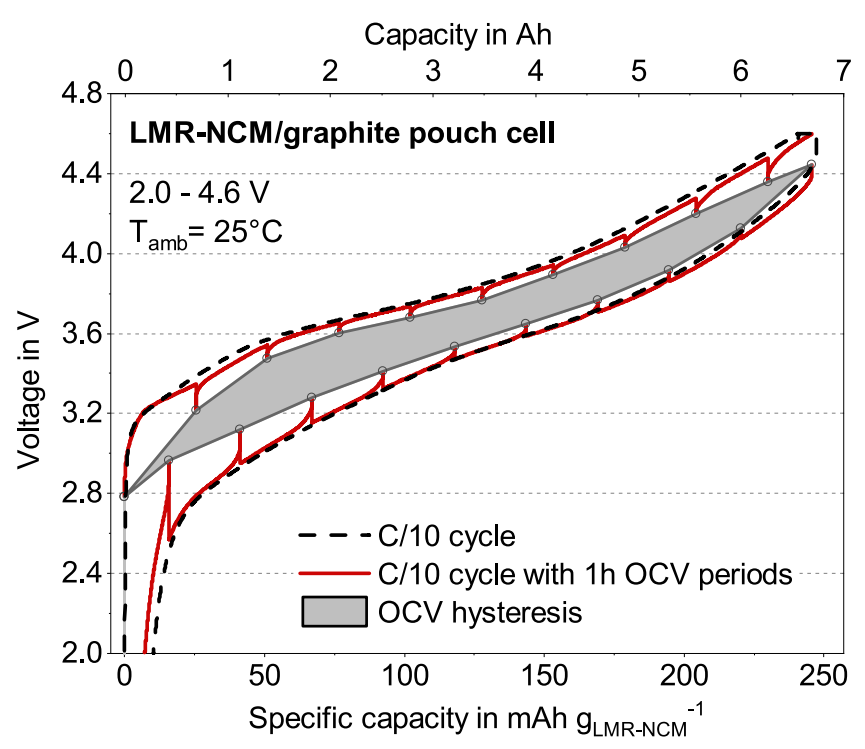

Figure 1. $\mathrm{C} / 10$ voltage profiles with and without $1 \mathrm{~h}$ OCV rest periods of an LMR-NCM/graphite pouch cell that was cycled in a voltage window of 2.0-4.6 V at an ambient temperature of $25^{\circ} \mathrm{C}$. Figure derived from Ref. 24.

Table I. Round-trip energy efficiencies of multilayer LMR-NCM/ graphite and NCA/graphite pouch cells with a nominal capacity of 6-7 Ah during a discharge rate capability test at an ambient temperature of $25{ }^{\circ} \mathrm{C}^{24}$ The temperatures were measured on the surface of the pouch cells within cell holders and the stated maximum surface temperatures $T_{\max \text {, surf }}$ were reached during the discharge.

\begin{tabular}{|c|c|c|c|c|}
\hline \multirow{2}{*}{$\begin{array}{l}\mathrm{DCH} \\
\text { C-rate }\end{array}$} & \multicolumn{2}{|c|}{ LMR-NCM/graphite } & \multicolumn{2}{|c|}{ NCA/graphite } \\
\hline & $\mathrm{EE}$ & $T_{\mathrm{max}, \text { surf }}$ & $\mathrm{EE}$ & $T_{\max , \text { surf }}$ \\
\hline $\mathrm{C} / 10$ & $88 \%$ & $27^{\circ} \mathrm{C}$ & $98 \%$ & $27^{\circ} \mathrm{C}$ \\
\hline $1 \mathrm{C}$ & $81 \%$ & $36^{\circ} \mathrm{C}$ & $92 \%$ & $28^{\circ} \mathrm{C}$ \\
\hline $3 \mathrm{C}$ & $70 \%$ & $53{ }^{\circ} \mathrm{C}$ & $85 \%$ & $33^{\circ} \mathrm{C}$ \\
\hline
\end{tabular}

Note. DCH—discharge, EE—round-trip energy efficiency.

were manufactured on the pilot scale production line at the Technical University of Munich. ${ }^{27}$ The C/10 voltage profiles of an LMR-NCM/ graphite pouch cell are displayed in Fig. 1. By adding $1 \mathrm{~h}$ open circuit voltage (OCV) rest periods, the voltage difference between charge and discharge can be approximately separated into a voltage drop due to overpotentials during cycling and the LMR-NCM OCV hysteresis. ${ }^{24}$ The overpotentials are caused by poor charge transfer kinetics and/or a slow solid-state diffusion of LMR-NCM, especially at low states-of-charge (SOC). ${ }^{17,28,29}$ While there still is a minimal voltage relaxation after $1 \mathrm{~h} \mathrm{OCV}$, an $\mathrm{OCV}$ hysteresis remains for LMR-NCM materials even after resting periods of several days. ${ }^{20,30}$

In a discharge rate capability test, the LMR-NCM/graphite pouch cells reached $\approx 81 \%$ round-trip energy efficiency for a 1C discharge, while the NCA/graphite pouch cells reached $\approx 92 \% .{ }^{24}$ These values are in very good agreement with the values stated by Meister et al. ${ }^{26}$ if NCA is considered to have a similar energy efficiency like NMC111. The discharge rate capability tests also revealed a strong increase in cell temperature for the LMR-NCM/graphite pouch cells with increasing discharge currents, which can be ascribed to the energy loss due to overpotentials and the LMR-NCM OCV hysteresis. The gray shaded area in Fig. 1 indicates the approximate share of the OCV hysteresis of LMR-NCM, which is presumably currentindependent, and the electrical work that is lost due to such a voltage hysteresis is most likely dissipated as waste heat. ${ }^{20,24}$ So with rising C-rates, the share of the irreversible heat due to overpotentials likely dominates the total heat generation. In Table I, the round-trip energy efficiencies and maximum surface temperatures for the two pouch cell types are stated (taken from Ref. 24). For a C/10 discharge, both cell types kept approximately the same temperature, but for a $3 \mathrm{C}$ discharge, the LMR-NCM/graphite pouch cells reached surface temperatures of $53{ }^{\circ} \mathrm{C}$, while the NCA/graphite pouch cells only reached $33{ }^{\circ} \mathrm{C}$. In smaller laboratory-scale cell formats, the generated heat poses no further problems, but when it comes to larger cell formats, the thermal behavior of cells containing LMRNCM cannot be neglected.

The temperature has a high impact on the performance of lithium-ion cells, and with the aid of thermal models, various cooling strategies can be analyzed and optimized. There are thermal models of the cell itself, which are often coupled with electrochemical models, ${ }^{31-39}$ but also thermal models that describe the whole battery pack including the corresponding cooling system. ${ }^{40-43}$ In the coupled models, the heat generation is usually computed based on the electrochemical model, i.e., the irreversible losses described by currents and overpotentials plus the reversible heat. However, especially the electrochemical models of lithium-ion cells are based on an extensive parameter set consisting of more than 30 parameters. ${ }^{32,33,37}$ Not all of these parameters can be experimentally determined and are either taken from literature or have to be assumed.

In this work, the thermal behavior of LMR-NCM/graphite cells is investigated and compared to NCA/graphite cells and the consequences for operating strategies and thermal management systems are derived. The focus is on the total heat generation and not on a characterization of the different heat sources. To quantify the heat generation for different charge and discharge rates, isothermal calorimetric measurements were performed on laboratory coin cells for the cell systems LMR-NCM/graphite and NCA/graphite. The determined heat generation was scaled to various cell formats and used as an input parameter for a homogenized 3D thermal model to qualitatively assess the thermal behavior. Simulation studies analyzed the implications of the heat generation on the temperature development especially in large-format batteries and the resulting requirements for their thermal management system. Particularly, the interplay between the cell size, the applied load, and the thermal boundary conditions of the cooling system was evaluated and design criteria for cells containing LMR-NCM were derived.

\section{Experimental}

Electrode specifications.-The LMR-NCM cathodes have a stoichiometry of $0.33 \mathrm{Li}_{2} \mathrm{MnO}_{3} \cdot 0.67 \mathrm{LiNi}_{0.38} \mathrm{Co}_{0.21} \mathrm{Mn}_{0.41} \mathrm{O}_{2}$ (BASF, Germany), which can also be written as $\mathrm{Li}_{1.14}\left[\mathrm{Ni}_{0.26} \mathrm{Co}_{0.14} \mathrm{Mn}_{0.60}\right]_{0.86} \mathrm{O}_{2}$, and the NCA cathodes have a stoichiometry of $\mathrm{LiNi}_{0.81} \mathrm{Co}_{0.15} \mathrm{Al}_{0.04} \mathrm{O}_{2}$ (BASF, Germany). The cathode coatings were prepared by mixing $92.5 \mathrm{wt} \%$ CAM (LMR-NCM or NCA), $4 \mathrm{wt} \%$ conductive carbon (Super-C65, Timcal, Switzerland), and $3.5 \mathrm{wt} \%$ polyvinylidene-fluoride binder (PVdF, Solef 5130, Solvay, Belgium) with N-methyl-2-pyrrolidone (NMP, anhydrous, 99.5\%, Sigma-Aldrich, Germany) at a solid content of $57 \mathrm{wt} \%$ and $62 \mathrm{wt} \%$ for LMR-NCM and NCA, respectively. The mixing was performed in several steps using a planetary orbital mixer (Thinky, USA). The final slurry was cast onto one side of a $15 \mu \mathrm{m}$ aluminum foil (MTI, USA) using a $200 \mu \mathrm{m}$ four-edge blade. The CAM loading was set to $11.5 \mathrm{mg} \mathrm{cm}^{-2}\left(\equiv 2.9 \mathrm{mAh} \mathrm{cm}^{-2}\right.$ at $\mathrm{C} / 10$, based on a nominal capacity of $\left.250 \mathrm{mAh} \mathrm{g}_{\mathrm{CAM}}^{-1}\right)$ and $12.5 \mathrm{mg} \mathrm{cm}^{-2}\left(\equiv 2.5 \mathrm{mAh} \mathrm{cm}^{-2}\right.$ at $\mathrm{C} / 10$, based on a nominal capacity of $200 \mathrm{mAh} \mathrm{g}_{\mathrm{CAM}}^{-1}$ ) for the LMR-NCM and NCA electrode sheets, respectively. The coated cathode foils were dried overnight in a convection oven at $50{ }^{\circ} \mathrm{C}$ and afterwards compressed in a calender (GK 300-L, Saueressig, Germany) to a porosity of $42 \%$, resulting in coating thicknesses of $\approx 54 \mu \mathrm{m}(\mathrm{LMR}-\mathrm{NCM})$ and $\approx 56 \mu \mathrm{m}$ (NCA).

The corresponding anode coatings were prepared by mixing $95 \mathrm{wt} \%$ graphite (SGL Carbon, Germany) and $5 \mathrm{wt} \%$ PVdF binder (Solef 5130, Solvay, Belgium) with NMP (anhydrous, 99.5\%, 
Table II. Specifications of the LMR-NCM/graphite and NCA/graphite coin cells. The nominal cell capacities were calculated with reversible capacities of $250 \mathrm{mAh} \mathrm{g}^{-1}$ for LMR-NCM and $200 \mathrm{mAh} \mathrm{g}^{-1}$ for NCA.

\begin{tabular}{lccc} 
Type & Cell & CAM mass & Nominal cell capacity \\
\hline \multirow{2}{*}{ LMR-NCM/graphite } & L1 & $17.834 \mathrm{mg}$ & $4.459 \mathrm{mAh}$ \\
& L2 & $17.603 \mathrm{mg}$ & $4.401 \mathrm{mAh}$ \\
NCA/graphite & N1 & $19.518 \mathrm{mg}$ & $3.904 \mathrm{mAh}$ \\
& N2 & $19.795 \mathrm{mg}$ & $3.959 \mathrm{mAh}$
\end{tabular}

Note. CAM—cathode active material

Sigma-Aldrich, Germany) at a solid content of $54 \mathrm{wt} \%$ and $52 \mathrm{wt} \%$ for the respective LMR-NCM and NCA electrodes. As before, this was performed in several steps in a planetary orbital mixer (Thinky, USA). The final slurry was cast onto one side of a $12 \mu \mathrm{m}$ copper foil (Gelonlib, China) using a $200 \mu \mathrm{m}$ four-edge blade. The graphite electrode loadings were set to $10.3 \mathrm{mg} \mathrm{cm}^{-2}$ ( $\equiv 3.7 \mathrm{mAh} \mathrm{cm}^{-2}$ at $\mathrm{C}$ / 10 , based on a nominal capacity of $355 \mathrm{mAh} \mathrm{g}_{\text {graphite }}^{-1}$ ) for LMR$\mathrm{NCM}$ and $9.4 \mathrm{mg} \mathrm{cm}^{-2}\left(\equiv 3.3 \mathrm{mAh} \mathrm{cm}^{-2}\right.$ at $\mathrm{C} / 10$, based on a nominal capacity of $355 \mathrm{mAh} \mathrm{g}_{\text {graphite }}^{-1}$ ) for NCA based coin cells. The coated anode foils were dried overnight in a convection oven at $50{ }^{\circ} \mathrm{C}$ and afterwards compressed in a calender (GK 300-L, Saueressig, Germany) to a porosity of $30 \%$, resulting in anode coating thicknesses of $\approx 69 \mu \mathrm{m}$ (for LMR-NCM) and $\approx 63 \mu \mathrm{m}$ (for NCA). The resulting areal capacity ratios of negative/positive electrode (N/P ratio) were around 1.3 for both cell setups.

Coin cell preparation.-The cathode coins were punched out of the electrode sheets with a diameter of $14 \mathrm{~mm}$, and the anode coins with a diameter of $15 \mathrm{~mm}$. The coin cells in the 2032 format were assembled in an argon filled glove box (M. Braun Inertgas-Systeme, Germany) with $\mathrm{H}_{2} \mathrm{O}<0.1 \mathrm{ppm}$ and $\mathrm{O}_{2}<0.1 \mathrm{ppm}$. Each cell was filled with $80 \mu \mathrm{l}$ of electrolyte. The LMR-NCM/graphite cells were filled with a $1 \mathrm{M}$ solution of $\mathrm{LiPF}_{6}$ in $12 \mathrm{vol} \%$ FEC, $64 \mathrm{vol} \%$ DEC, $24 \mathrm{vol} \%$ co-solvent, and $2 \mathrm{wt} \%$ of a proprietary additive (BASF, Germany), while the NCA/graphite cells were filled with a $1 \mathrm{M}$ solution of $\mathrm{LiPF}_{6}$ in a 3:7 (by weight) mixture of EC:DEC and $2 \mathrm{wt} \%$ vinylene carbonate (VC, BASF, Germany). A glass fiber separator (Type 691, VWR, USA) with $17 \mathrm{~mm}$ diameter and two $1 \mathrm{~mm}$ spacers were used. The specifications of the four coin cells (2x LMR-NCM/graphite and 2x NCA/graphite) used for the calorimetric measurements are listed in Table II. The nominal cell capacities were calculated based on the amount of CAM with reversible capacities of $250 \mathrm{mAh} \mathrm{g}^{-1}$ (LMR-NCM) and $200 \mathrm{mAh} \mathrm{g}^{-1}$ (NCA). All later used $\mathrm{C}$-rates in the measurements are referenced to the stated capacities for each cell.

After cell assembly, a formation procedure including one $\mathrm{C} / 15$ charge/discharge cycle and two $\mathrm{C} / 10$ charge/discharge cycles was carried out with a Maccor cycler (series 4000, USA) in a thermostatic chamber (Binder, Germany) at $25^{\circ} \mathrm{C}$. In the first formation cycle, the LMR-NCM/graphite cells were charged to $4.7 \mathrm{~V}$ in order to activate the LMR-NCM. ${ }^{17}$ The following cycles were carried out in the voltage window $2.0-4.6 \mathrm{~V}$. The $\mathrm{NCA} /$ graphite cells were cycled in the voltage window $3.0-4.3 \mathrm{~V}$.

Calorimetric measurements.-After formation, the coin cells were transferred to an isothermal heat flow calorimeter setup (TAM IV, TA Instruments, USA), consisting of a thermostat (stability $\pm 50 \mu \mathrm{K}$ ) equipped with a $20 \mathrm{ml}$ microcalorimeter (accuracy $\pm 300 \mathrm{nW}$, precision $\pm 100 \mathrm{nW}$ ) and a custom-made coin cell holder. Over the duration of the experiment, the baseline drift was less than $500 \mathrm{nW}$. The step response of the heat flow resulted in a delay time of $750 \mathrm{~s}$ until $95 \%$ of the heat flow signal were detected. All measurements were performed in isothermal mode at $25^{\circ} \mathrm{C}$ after internal gain calibration. The cells were connected over $\mathrm{Cu}-\mathrm{P}$ bronze DuoTwist wires (36 AWG, Lakeshore, USA) to a multi-channel potentiostat (VSP, BioLogic, France).

Detailed measurement procedures including the formation are listed in Table III. After installing the coin cells into the calorimeter, a first $\mathrm{C} / 10$ stabilization cycle was carried out to ensure a proper cell and calorimeter functionality. The subsequent cycles were conducted to precisely measure the heat generation during different constant current (CC) charge and discharge operations, namely $\mathrm{C} / 10, \mathrm{C} / 2,1 \mathrm{C}$, $2 \mathrm{C}$, and $3 \mathrm{C}$. Before each $\mathrm{CC}$ charge or discharge cycle, a pause of $4 \mathrm{~h}$ was added to allow a relaxation of the heat in the calorimeter. After each CC charge/discharge, a pause of $30 \mathrm{~min}$ was added to

Table III. Measurement procedures applied to the LMR-NCM/graphite and NCA/graphite coin cells. After the first three formation cycles, the cells were cycled in the calorimeter.

Procedure

C/15 formation cycle

$\mathrm{C} / 10$ formation cycle $(2 \mathrm{x})$

C/10 stabilization cycle

$\mathrm{C} / 10$ cycle

Cycle test
Parameters

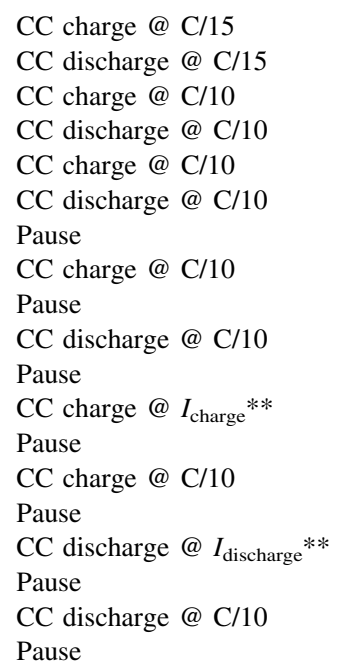

Stop condition

$U \geqslant U_{\max } *$

$U \leqslant U_{\text {min }}$

$U \geqslant U_{\max }$

$U \leqslant U_{\text {min }}$

$U \geqslant U_{\max }$

$U \leqslant U_{\text {min }}$

$t \geqslant 4 \mathrm{~h}$

$U \geqslant U_{\max }$

$t \geqslant 4 \mathrm{~h}$

$U \leqslant U_{\text {min }}$

$t \geqslant 4 \mathrm{~h}$

$U \geqslant U_{\max }$

$t \geqslant 30 \mathrm{~min}$

$U \geqslant U_{\max }$

$t \geqslant 4 \mathrm{~h}$

$U \leqslant U_{\text {min }}$

$t \geqslant 30 \mathrm{~min}$

$U \leqslant U_{\text {min }}$

$t \geqslant 4 \mathrm{~h}$

Note. The C-rates refer to the nominal cell capacities listed in Table II. CC-constant current, CV-constant voltage. LMR-NCM: $U_{\max }=4.6 \mathrm{~V}, U_{\min }=2.0 \mathrm{~V}$. NCA: $U_{\max }=4.3 \mathrm{~V}, U_{\min }=3.0 \mathrm{~V}$. $*$ In their first C/15 formation cycle, the LMR-NCM/graphite cells were charged to $4.7 \mathrm{~V}$ to activate the CAM. $* * I_{\text {charge }}=I_{\text {discharge }}=[\mathrm{C} / 2,1 \mathrm{C}, 2 \mathrm{C}, 3 \mathrm{C}]$. 
measure the inert heat that was generated. Thereafter, the cells were either fully charged or discharged with a $\mathrm{C} / 10 \mathrm{CC}$ procedure to ensure consistent starting conditions: The cells were charged with a $\mathrm{C} / 10 \mathrm{CC}$ to a SOC of $100 \%$ before a discharge procedure and were discharged with a $\mathrm{C} / 10 \mathrm{CC}$ to a SOC of $0 \%$ before a charge procedure.

Cell formats.-Cell formats of lithium-ion cells are categorized into cylindric, prismatic, and pouch. Based on double-sided anodes and cathodes with separators in between, the electrode stack or jelly roll is adapted to the desired cell format. Pouch cells use stacked electrodes, cylindrical cells wound electrodes, and prismatic cells either flat wound or stacked electrodes. ${ }^{44-46}$ A schematic overview is illustrated in Fig. 2, together with the stated electrode thicknesses of the coin cells, assuming double-sided electrodes and a $25 \mu \mathrm{m}$ separator.

Via the thickness of the electrode stack, the total electrode area of any desired cell format can be calculated. A multiplication of the total electrode area with the areal capacity yields the nominal capacity $C_{\mathrm{N}}$ of the cell. By further multiplying $C_{\mathrm{N}}$ with the mean discharge voltage, the nominal energy $E_{\mathrm{N}}$ of the cell can be calculated. In this work, the geometric dimensions of the pouch and prismatic cells were taken from the standard DIN 91252. ${ }^{9}$ In this standard, the thickness of the pouch cell formats is not specified, however, in the corresponding pre-standard a maximum thickness of $13 \mathrm{~mm}$ was defined. For our calculations, the HEV and PHEV pouch cells were assumed with a thickness of $10 \mathrm{~mm}$, while the BEV pouch cells were assumed with a thickness of $13 \mathrm{~mm}$. In addition to the standardized prismatic and pouch cell formats, the cylindric cell formats 18650,21700 , and 26650 were investigated, as shown in Table IV.

The calculation of the nominal capacity and energy content of the listed cell formats is based on the electrodes of the coin cells described above, only double-sided, and a $25 \mu \mathrm{m}$ separator. According to Fig. 2, the electrode stack consists of one doublesided anode, one double-sided cathode, and two separators. The LMR-NCM/graphite electrode stack has a total thickness of $323 \mu \mathrm{m}$, an areal capacity of $2.9 \mathrm{mAh} \mathrm{cm}^{-2}$, and a mean discharge voltage of
3.5 V for a C/10 discharge. The NCA/graphite electrode stack has a total thickness of $315 \mu \mathrm{m}$, an areal capacity of $2.5 \mathrm{mAh} \mathrm{cm}^{-2}$, and a mean discharge voltage of $3.7 \mathrm{~V}$. The cells were not optimized toward a high energy density, in fact, they served as a CAM characterization in comparable cell designs. The resulting surface to volume (S/V) ratio of each cell format was calculated with the outer surface of the cell case and the effective volume of the jelly roll/ electrode stack and not the total inner volume of each cell case.

For the calculation of the larger pouch cell formats as stated in the standard DIN 91252, ${ }^{9}$ a pouch foil thickness of $153 \mu \mathrm{m}$ (D-EL408PH-3, DNP, Japan) was used, and tabs as well as empty spaces between the foil and the electrode stack were neglected. The geometric dimensions are given in Fig. 3a. The thickness of the hard case of the prismatic cells was assumed to be $0.7 \mathrm{~mm} .{ }^{31}$ The highest utilization of the hard case volume can be achieved by stacking the electrodes. However, stacking includes more processing steps and time compared to flat winding and errors are more likely. ${ }^{45,46}$ In our calculations, a flat wound jelly roll with an axial orientation in the $y$-direction of the prismatic cell formats was presumed. The spaces between the hard case and the jelly roll are displayed in Fig. $3 b$. According to the study of Quinn et al., ${ }^{8}$ the can of cylindric cells has a thickness of $0.2 \mathrm{~mm}$ and contains a $5 \mathrm{~mm}$ head space for contacting and safety devices. For the 3D thermal model, the $5 \mathrm{~mm}$ were divided into a $1 \mathrm{~mm}$ bottom and $4 \mathrm{~mm}$ top head space, as seen in Fig. 3c. The $1 \mathrm{~mm}$ inner void of the jelly roll originates from the winding process. Possible separator overlaps and anode overhang areas, as well as single-sided anodes at the beginning and end of each stack or jelly roll were neglected in the calculations.

\section{Modeling}

According to the description of the different cell formats in the experimental section, the geometric dimensions of the cell cases including the electrode stack/jelly roll were integrated in a 3D thermal model, which uses the scaled heat generation of the calorimetry measurements as an input parameter. The 3D thermal model was implemented in the commercial FEM solver COMSOL Multiphysics 5.4. To reduce computational complexity, the jelly roll/

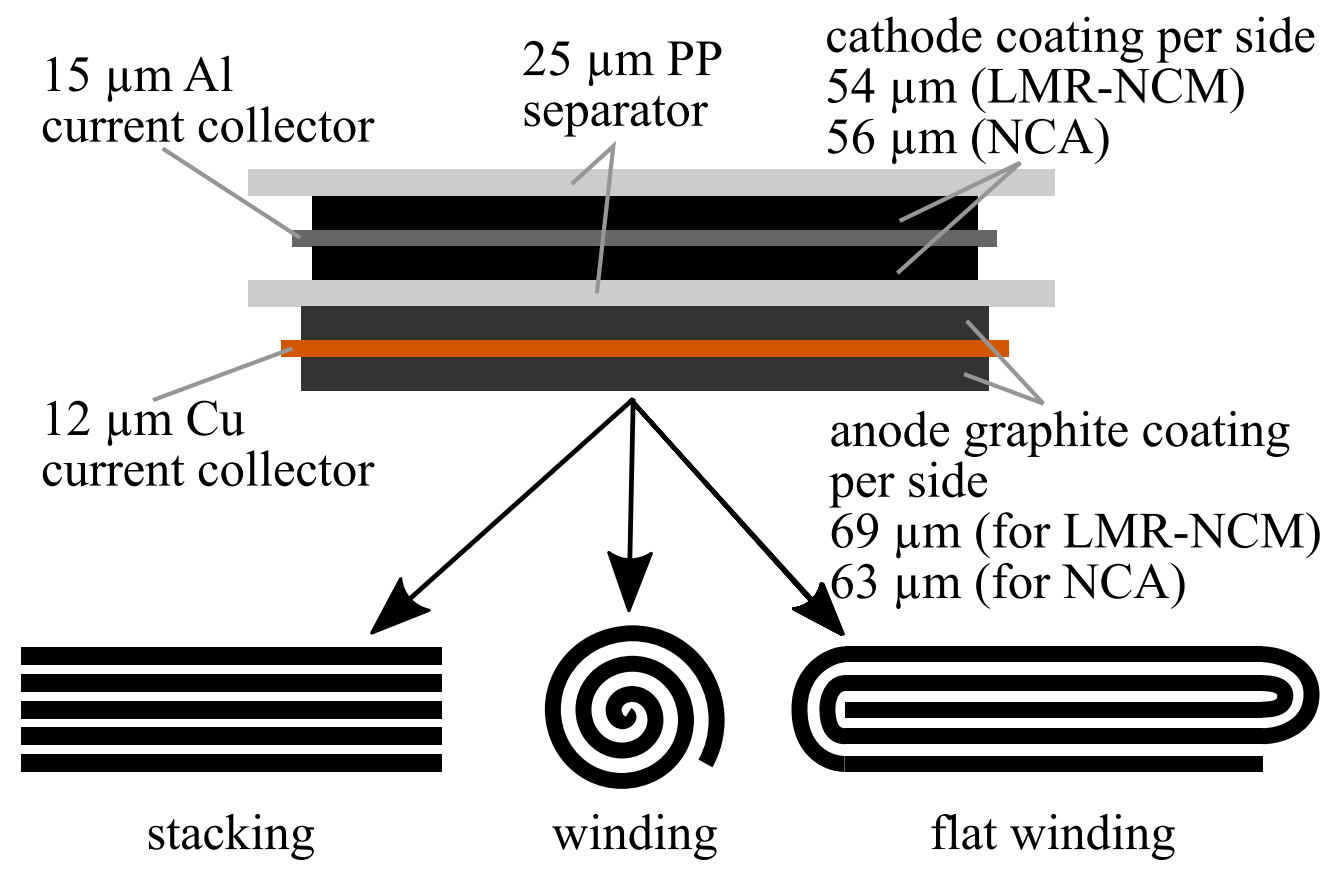

Figure 2. Schematic electrode stack consisting of double-sided anodes and cathodes with separators in between. Stacking the layers is used for pouch cells, winding for cylindric cells, and flat winding or stacking for prismatic cells. The stated coating thicknesses represent the coating thickness per side of double-sided electrodes. 
Table IV. Geometric dimensions of the investigated cell formats including their scaled nominal capacity and energy content. For the calculations, the areal capacity and mean discharge voltage for a C/10 discharge of the LMR-NCM/graphite and NCA/graphite coin cells were used. The surface to volume $(\mathrm{S} / \mathrm{V})$ ratio was calculated based on the effective volume of the jelly roll/electrode stack and not the total inner volume.

\begin{tabular}{|c|c|c|c|c|c|c|c|c|c|}
\hline \multirow[b]{2}{*}{ Cell format } & & \multirow[b]{2}{*}{$\begin{array}{c}x \\
\text { in } \mathrm{mm}\end{array}$} & \multirow[b]{2}{*}{$\begin{array}{l}y \\
\text { in } \mathrm{mm}\end{array}$} & \multirow[b]{2}{*}{$\begin{array}{c}z \\
\text { in } \mathrm{mm}\end{array}$} & \multirow{2}{*}{ 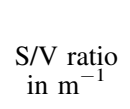 } & \multicolumn{2}{|c|}{ LMR-NCM/graphite } & \multicolumn{2}{|c|}{ NCA/graphite } \\
\hline & & & & & & $C_{\mathrm{N}}$ in $\mathrm{Ah}$ & $E_{\mathrm{N}}$ in Wh & $C_{\mathrm{N}}$ in $\mathrm{Ah}$ & $E_{\mathrm{N}}$ in Wh \\
\hline \multirow[t]{5}{*}{ Pouch } & HEV & 161 & 141 & 10 & 2.3 & 39 & 138 & 35 & 128 \\
\hline & PHEV1 & 164.2 & 226 & 10 & 2.3 & 64 & 225 & 56 & 209 \\
\hline & PHEV2 & 164 & 232 & 10 & 2.3 & 66 & 231 & 58 & 214 \\
\hline & BEV1 & 99.7 & 301.5 & 13 & 1.9 & 68 & 237 & 60 & 222 \\
\hline & $\mathrm{BEV} 2$ & 329.2 & 161.4 & 13 & 1.8 & 120 & 420 & 106 & 392 \\
\hline \multirow[t]{10}{*}{ Prismatic } & HEV1 & 85 & 120 & 12.5 & 2.6 & 15 & 53 & 14 & 50 \\
\hline & HEV2 & 80.5 & 120 & 12.1 & 2.7 & 14 & 48 & 12 & 45 \\
\hline & PHEV1 & 85 & 173 & 21 & 1.6 & 41 & 144 & 37 & 135 \\
\hline & PHEV2 & 91 & 148 & 26.5 & 1.3 & 48 & 169 & 43 & 158 \\
\hline & BEV1 & 115 & 173 & 32 & 1.1 & 90 & 315 & 79 & 293 \\
\hline & BEV2 & 115 & 173 & 45 & 0.8 & 127 & 445 & 113 & 416 \\
\hline & BEV3 & 125 & 173 & 32 & 1.0 & 98 & 345 & 87 & 321 \\
\hline & BEV4 & 125 & 173 & 45 & 0.8 & 139 & 487 & 123 & 455 \\
\hline & & $d$ & $h$ & & $\mathrm{~S} / \mathrm{V}$ ratio & \multicolumn{2}{|c|}{ LMR-NCM/graphite } & \multicolumn{2}{|c|}{ NCA/graphite } \\
\hline & & in $\mathrm{mm}$ & in $\mathrm{mm}$ & & in $\mathrm{m}^{-1}$ & $C_{\mathrm{N}}$ in $\mathrm{Ah}$ & $E_{\mathrm{N}}$ in $\mathrm{Ah}$ & $C_{\mathrm{N}}$ in $\mathrm{Ah}$ & $E_{\mathrm{N}}$ in $\mathrm{Wh}$ \\
\hline \multirow{3}{*}{ Cylindric } & 18650 & 18 & 65 & & 2.9 & 2.6 & 9.1 & 2.3 & 8.5 \\
\hline & 21700 & 21 & 70 & & 2.5 & 3.9 & 13.5 & 3.4 & 12.6 \\
\hline & 26650 & 26 & 65 & & 2.1 & 5.5 & 19.3 & 4.9 & 18.0 \\
\hline
\end{tabular}

Note. LMR-NCM/graphite: $2.9 \mathrm{mAh} \mathrm{cm}{ }^{-2}, 3.5 \mathrm{~V} @ \mathrm{C} / 10$ discharge. NCA/graphite: $2.5 \mathrm{mAh} \mathrm{cm} \mathrm{cm}^{-2}, 3.7 \mathrm{~V} @ \mathrm{C} / 10$ discharge.

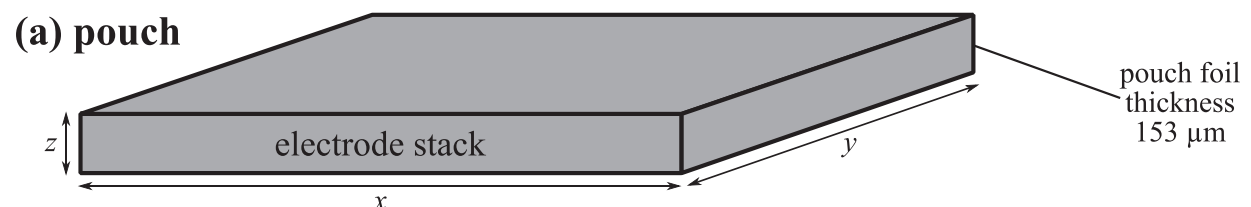

(b) prismatic

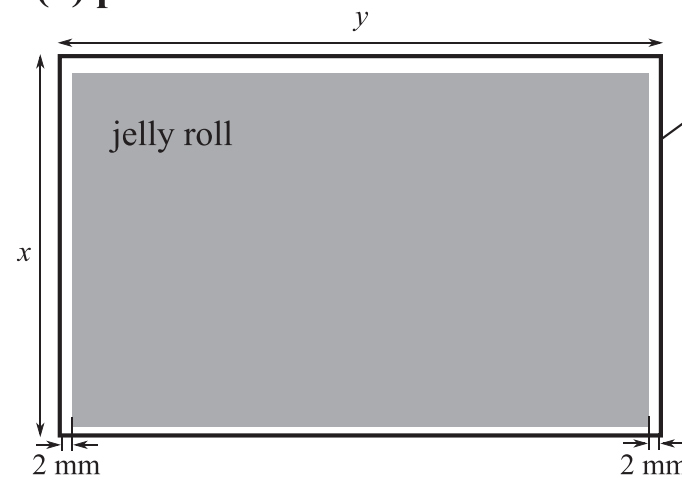

hard case thickness $0.7 \mathrm{~mm}$

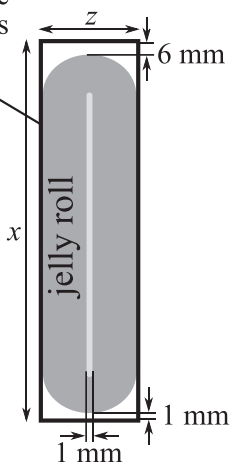

(c) cylindric

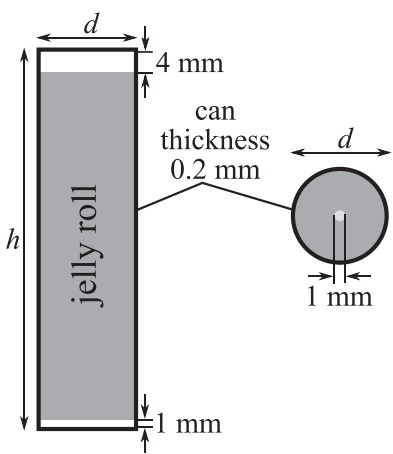

Figure 3. Geometric dimensions of the (a) pouch, (b) prismatic, and (c) cylindric cell formats including the assumed head spaces and inner voids of the jelly rolls as well as the respective case thicknesses.

electrode stack was homogenized with an anisotropic thermal conductivity perpendicular and parallel to the layers. Therefore, each thermal model consists of two different domains, the jelly roll/ electrode stack and the case. Within these domains, the general heat balance is solved. ${ }^{31,47}$

$$
\rho c_{\mathrm{p}} \frac{\partial T}{\partial t}=\nabla(k \nabla T)+q,
$$

where $\rho$ is the density in $\mathrm{kg} \mathrm{m}^{-3}, c_{\mathrm{p}}$ the specific heat capacity in $\mathrm{J} \mathrm{kg}^{-1} \mathrm{~K}^{-1}, T$ the temperature in $\mathrm{K}, q$ the volumetric heat generation in $\mathrm{W} \mathrm{m}^{-3}$, and $k$ the thermal conductivity in $\mathrm{W} \mathrm{m}^{-1} \mathrm{~K}^{-1}$. The thermal conductivity $k$ is defined via its values in $x$-, $y$-, and $z$-direction:

$$
k=\left[\begin{array}{ccc}
k_{\mathrm{x}} & 0 & 0 \\
0 & k_{\mathrm{y}} & 0 \\
0 & 0 & k_{\mathrm{z}}
\end{array}\right]
$$

Finally, the $\nabla$ operator (transpose) is defined in the 3D model as:

$$
\nabla=\left(\frac{\partial}{\partial x}, \frac{\partial}{\partial y}, \frac{\partial}{\partial z}\right)^{\mathrm{T}}
$$

The 3D thermal models with the homogenized jelly roll/electrode stack had in between 135000-280000 degrees of freedom (DOF) 
depending on the cell format and the boundary conditions (as specified below) and were able to solve within a few minutes on a desktop computer.

Thermal model parameters.-For the cylindric cells, as well as the wound part at the top and bottom of the jelly roll of the prismatic cells, a cylindric coordinate system was used. The corresponding values for the parameterization of the thermal model are stated in Table V. The density, the heat capacity, and the thermal conductivities of the jelly roll/electrode stack were calculated in the Appendix based on the values in Table A.I. These parameters can be calculated with the material properties and thicknesses of the current collectors, composite electrodes, separator, and electrolyte. ${ }^{14,31,47}$ However, it is difficult to get proper measurement values especially for the porous electrodes with varying compositions and active materials, which are soaked with electrolyte. In the literature, reported values of electrode densities $\rho$ are within the range $920-1040 \mathrm{~kg} \mathrm{~m}^{-3}$, and values of specific heat capacities $c_{\mathrm{p}}$ within the range $2560-2781 \mathrm{~J} \mathrm{~kg}^{-1} \mathrm{~K}^{-1} \cdot 14,37,48,49$ Reported values of the thermal through-plane conductivity $k_{\perp}$ of electrode stacks are within the range $0.9-1.1 \mathrm{~W} \mathrm{~m}^{-1} \mathrm{~K}^{-1}$ and of the thermal in-plane conductivity $k_{\|}$within $24.6-33.9 \mathrm{~W} \mathrm{~m}^{-1} \mathrm{~K}^{-1}$. 31,37,39,47 Steinhardt et al. ${ }^{50}$ investigated the thermal conductivity of the jelly roll/electrode stack based on different material combinations and calculated median values of $k_{\perp}=0.878 \mathrm{~W} \mathrm{~m}^{-1} \mathrm{~K}^{-1}$ and $k_{\|}=26.5 \mathrm{~W} \mathrm{~m}^{-1} \mathrm{~K}^{-1}$. The reported literature values are in good agreement with our calculations. A constant anisotropic thermal conductivity of the electrode stack $\left(k_{\perp}=0.83 \mathrm{~W} \mathrm{~m}^{-1} \mathrm{~K}^{-1}\right.$, $k_{\|}=27.3 \mathrm{~W} \mathrm{~m}^{-1} \mathrm{~K}^{-1}$ ) was used for our modeling purposes, but a variable, temperature-dependent conductivity may be implemented in future work, especially if high temperature changes are expected.

The volumetric heat generation $q$ is a function of the cell SOC and was measured for varying charge/discharge currents using isothermal calorimetry as described in the experimental section. The measured heat generation was related to the cathode area of the coin cells $\left(1.54 \mathrm{~cm}^{2}\right)$, scaled to the total cathode area of each cell format, and finally ascribed to the domain of the homogenized jelly roll/electrode stack in the model.

Pouch foils usually consist of an aluminum foil that is laminated with diverse plastics on both sides. As an example, the $153 \mu$ m thick pouch foil D-EL408PH-3 (DNP, Japan) uses layers of polyethylene terephthalate (PET), polyamide (PA), and polypropylene (PP) around an inner aluminum foil. Accurate layer thicknesses of the different materials are not known, so a uniform heat capacity and an isotropic thermal conductivity of the pouch foil were estimated as a compound between the thermal characteristics of the plastics and the aluminum. The density of the pouch foil was determined by the areal weight and the thickness as stated in the data sheet. In the 3D model of the pouch cell, all boundary areas of the inner electrode stack were enclosed with the pouch foil.

For the hard case of a prismatic cell, an aluminum alloy is often used to ensure mechanical stability without adding too much weight. $^{37,52}$ For the model parameters of the prismatic case, the thermal characteristics of the aluminum alloy 2024 with a thickness of $0.7 \mathrm{~mm}$ were chosen. ${ }^{31}$ The flat wound jelly roll is only in contact with the case on its two large lateral faces, as shown in Fig. 3b. The empty head spaces of prismatic cells are filled with argon, which possesses a low thermal conductivity $\left(0.0178 \mathrm{~W} \mathrm{~m}^{-1} \mathrm{~K}^{-1}\right)$ and a low heat capacity $\left(0.844 \mathrm{~kJ} \mathrm{~m}^{-3} \mathrm{~K}^{-1}\right){ }^{52}$ For modeling simplicity, all remaining boundaries of the jelly roll were thermally insulated and a heat transfer with the case was deactivated.

Cylindric cell cans are typically made of steel with a thickness of $0.17-0.25 \mathrm{~mm} .^{53,54}$ The thermal parameters in Table $\mathrm{V}$ are specified for the stainless steel AISI- $304^{31}$ with a thickness of $0.2 \mathrm{~mm}$. In the model, the wound jelly roll is in contact with the can on its lateral face. As stated in the description of the cell formats in the experimental section, gaps were implemented between the top and bottom area of the jelly roll and the can, see Fig. 3c, which prohibit a heat transfer on these boundaries.

Boundary conditions. - The boundary conditions of thermal models depend on the use of the cells in a certain application including its thermal management system. This can imply that a single cell is directly mounted in an application with no cooling system at all, e.g., in mobile phones, tablets, or laptops. Reportedly, the early Nissan Leaf models faced problems during charging operations as the heat of the battery system was only passively dissipated. ${ }^{55,56}$ The charging and discharging performance is limited with a passive system, especially for warmer ambient temperatures, which is why most EVs rely on a liquid or refrigerant cooling system for their battery pack. ${ }^{56}$ Tesla uses cooling tubes around their cylindrical cells with a thermally conductive, electrically insulative material in between. ${ }^{57}$ Other car manufacturers use pouch or prismatic cells with a base plate cooling. ${ }^{58-60}$

In our first simulation study, a convective heat transfer between the entire surface area of the cell case and a constant ambient temperature $T_{\infty}$ was modeled. The temperature $T_{\text {surf }}$ describes the temperature on the surface of the cell case, i.e., the surface of the can of a cylindric cell, the hard case of a prismatic cell, or the pouch foil of a pouch cell. The convective heat flux $q_{\text {conv }}$ in $\mathrm{W} \mathrm{m}^{-2}$ was modeled with the following equation and $h$ as the heat transfer coefficient in $\mathrm{W} \mathrm{m}^{-2} \mathrm{~K}^{-1}$.

$$
q_{\mathrm{conv}}=h\left(T_{\mathrm{surf}}-T_{\infty}\right)
$$

Feng et al. ${ }^{61}$ classified the heat transfer coefficients according to different cooling scenarios. In their work, natural convection in air is listed with a heat transfer coefficient of $5-25 \mathrm{~W} \mathrm{~m}^{-2} \mathrm{~K}^{-1}$ and forced convection in air with $15-250 \mathrm{~W} \mathrm{~m}^{-2} \mathrm{~K}^{-1}$. A better heat transfer up to $1000 \mathrm{~W} \mathrm{~m}^{-2} \mathrm{~K}^{-1}$ can be achieved with a liquid coolant directly surrounding the cell, which is rather difficult to implement in most applications. ${ }^{5,61}$

In our second simulation study, a base plate cooling scenario for prismatic cells was investigated. Thereby, the base plate of the prismatic cell is in direct contact with a cooled cooling plate. ${ }^{60} \mathrm{~A}$ constant temperature of the cooling plate of $20^{\circ} \mathrm{C}$ was assumed, and the starting temperature of the cell was also set to $20^{\circ} \mathrm{C}$ to start with a uniform temperature of the whole system. In the model, the boundary condition for the bottom of the case was therefore set to a constant temperature of $20^{\circ} \mathrm{C}$ :

$$
T_{\text {surf,bottom }}=20{ }^{\circ} \mathrm{C}=\text { const. }
$$

All other boundaries were thermally insulated, derived by the neighboring cells in a module on both sides and the electrical connection on the top.

Table V. Thermal modeling parameters of the homogenized jelly roll/electrode stack and the different cell cases. The parameters of the jelly roll/ electrode stack are based on material properties described in the Appendix in Table A.I.

$\begin{array}{lcccc}\text { Parameter } & \text { Unit } & \text { Jelly roll } & \text { Pouch foil } & \text { Case prism. } \\ \text { Heat capacity } c_{\mathrm{p}} & \mathrm{J} \mathrm{kg}^{-1} \mathrm{~K}^{-1} & 1049 & 1400 & 875 \\ \text { Density } \rho & \mathrm{kg} \mathrm{m}^{-3} & 2427 & 1441^{\mathrm{m}} & 477 \\ \text { Thermal conductivity through-plane } k_{\perp} & \mathrm{W} \mathrm{m}^{-1} \mathrm{~K}^{-1} & 0.83 & 0.33 & 2770 \\ \text { Thermal conductivity in-plane } k_{\|} & \mathrm{W} \mathrm{m}^{-1} \mathrm{~K}^{-1} & 27.3 & 0.33 & 170 \\ \end{array}$




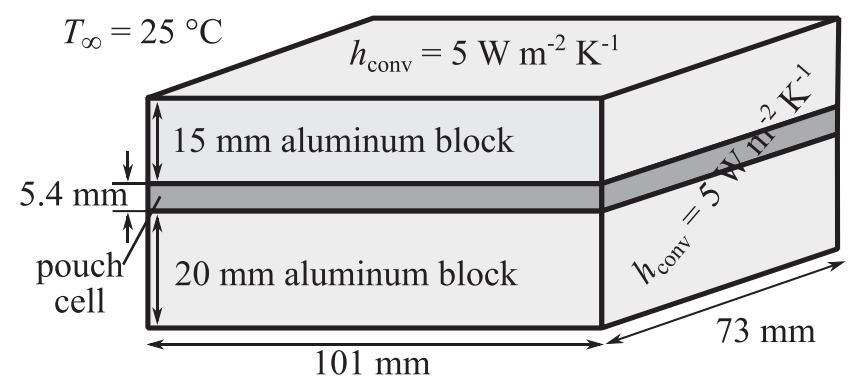

Figure 4. Schematic dimensions of the thermal validation model, representing the pouch cell within two aluminum blocks. The modeled thicknesses of the pouch cell were set to $5.5 \mathrm{~mm}$ (LMR-NCM/graphite) and $5.3 \mathrm{~mm}$ (NCA/graphite). The ambient temperature was set to $25^{\circ} \mathrm{C}$, and the convective heat transfer coefficient on the exterior surfaces to $5 \mathrm{~W} \mathrm{~m}^{-2} \mathrm{~K}^{-1}$.

Model validation.-The volumetric heat generation $q$ is a key input parameter of thermal models. In order to verify if a scaling of the heat generation measured in coin cells to larger cell formats is plausible, the thermal model needs to be validated with measurement data. Therefore, the temperature evolution of one LMR-NCM/ graphite and one NCA/graphite pouch cell measured in discharge rate capability tests in our previous work was used for comparison. ${ }^{24}$ During this test, the pouch cells were mounted in cell holders and the temperature was measured with a negative temperature coefficient (NTC) temperature sensor on the surface of the pouch cells with a precision of $\pm 1 \mathrm{~K}$ (compare Fig. 1 in Ref. 24). The LMR-NCM/ graphite pouch cell had a nominal capacity of $6.8 \mathrm{Ah}$ (27.3 g CAM), and the NCA/graphite pouch cell $6.3 \mathrm{Ah}$ (31.7 g CAM), to which the $\mathrm{C}$-rates in the discharge rate capability test were referred to. As the exact CAM mass was known for these cells, the heat generation for the thermal validation model was scaled via the CAM mass and not via the electrode area.
In the thermal validation model, the cell holder was represented by two aluminum blocks with thicknesses of $20 \mathrm{~mm}$ and $15 \mathrm{~mm}$, which were placed on the bottom and top of the pouch cell, respectively, as seen in Fig. 4. The stated thickness of the pouch cell of $5.4 \mathrm{~mm}$ represents a mean value; in the thermal model, the thicknesses of the pouch cells were set to $5.5 \mathrm{~mm}$ (LMR-NCM/ graphite) and $5.3 \mathrm{~mm}$ (NCA/graphite). The width and the depth of the two blocks were set to $73 \mathrm{~mm}$ and $101 \mathrm{~mm}$, which are the dimensions of the area of one cathode layer. For simplicity, anode and separator overhang areas as well as the pouch foil and cellulose sheets between pouch cell and cell holder were neglected in the validation model. The original cell holder (see Fig. 1 in Ref. 24) contained a polyoxymethylene (POM) frame around the aluminum blocks, which was in no direct contact with the cell and therefore left out. The thermal model parameters of the aluminum blocks were set to the ones of the prismatic aluminum case described in Table V. For each simulation, the starting temperatures of the pouch cells as well as the adjacent blocks were set to the starting temperature of the corresponding measurement. On the exterior surfaces of the aluminum blocks and the open side surface areas of the pouch cell, a convective heat transfer coefficient of $5 \mathrm{~W} \mathrm{~m}^{-2} \mathrm{~K}^{-1}$ was implemented, representing a natural convection without an active cooling. The ambient temperature was set to $25^{\circ} \mathrm{C}$ as the pouch cells were cycled in a controlled climate chamber at $25^{\circ} \mathrm{C}$. For detailed information about the pouch cell measurement procedures during this test as well as the cell holder, the reader is referred to the previous publication. ${ }^{24}$

\section{Results and Discussion}

This section is divided into the following parts: a presentation of the measured heat generation of the coin cells, and a validation of the thermal model with a scaled heat generation to the measured temperature of the pouch cells. Then, the results of two simulation studies, which were carried out for different standardized cell formats, are presented. The studies included one simulation with a

Table VI. Specific charge and discharge capacities and heat generation of one LMR-NCM/graphite (L1) and one NCA/graphite (N1) coin cell during the CC phases $\left(Q_{C C}\right)$ and the 30 min pauses $\left(Q_{\text {pause }}\right)$ afterwards. $Q_{\text {total }}$ is the sum of $Q_{C C}$ and $Q_{\text {pause }}$. $\Delta$ SOC was referred to the listed C/10 charge capacity of each cell type. The specific capacities and the heat are related to the CAM mass of the respective coin cell.

\begin{tabular}{|c|c|c|c|c|c|c|c|}
\hline Type & C-rate & $\begin{array}{l}\text { Capacity in } \\
\text { mAh } g_{\text {CAM }}^{-1}\end{array}$ & $\Delta \mathrm{SOC}$ & $\begin{array}{c}Q_{C C} \text { in } \\
\mathrm{mWh} \mathrm{g}_{\mathrm{CAM}}^{-1}\end{array}$ & $\begin{array}{c}Q_{\text {pause }} \text { in } \\
\mathrm{mWh}^{-1} \mathrm{~g}_{\text {CAM }}\end{array}$ & $\begin{array}{c}Q_{\text {total }} \text { in } \\
\mathrm{mWh} \mathrm{g}_{\mathrm{CAM}}^{-1}\end{array}$ & $Q_{C C} / Q_{\text {total }}$ \\
\hline \multicolumn{8}{|l|}{ Charge } \\
\hline \multirow{5}{*}{$\begin{array}{l}\text { LMR-NCM/ } \\
\text { graphite }\end{array}$} & $\mathrm{C} / 10$ & 231.7 & $100 \%$ & 26.4 & 2.6 & 29.0 & $91 \%$ \\
\hline & $\mathrm{C} / 2$ & 212.9 & $91.9 \%$ & 42.9 & 6.8 & 49.7 & $86 \%$ \\
\hline & $1 \mathrm{C}$ & 199.5 & $86.1 \%$ & 59.2 & 14.4 & 73.6 & $80 \%$ \\
\hline & $2 \mathrm{C}$ & 186.0 & $80.3 \%$ & 72.1 & 35.3 & 107.4 & $67 \%$ \\
\hline & $3 \mathrm{C}$ & 168.2 & $72.6 \%$ & 62.8 & 62.5 & 125.3 & $50 \%$ \\
\hline \multirow{5}{*}{$\begin{array}{l}\text { NCA/ } \\
\text { graphite }\end{array}$} & $\mathrm{C} / 10$ & 182.9 & $100 \%$ & 10.0 & 0.4 & 10.4 & $96 \%$ \\
\hline & $\mathrm{C} / 2$ & 175.5 & $96.0 \%$ & 18.7 & 2.1 & 20.8 & $90 \%$ \\
\hline & $1 \mathrm{C}$ & 165.4 & $90.4 \%$ & 25.9 & 6.1 & 32.0 & $81 \%$ \\
\hline & $2 \mathrm{C}$ & 148.9 & $81.4 \%$ & 33.3 & 17.1 & 50.4 & $66 \%$ \\
\hline & $3 C$ & 131.0 & $71.6 \%$ & 30.8 & 31.4 & 62.2 & $50 \%$ \\
\hline \multicolumn{8}{|l|}{ Discharge } \\
\hline \multirow{5}{*}{$\begin{array}{l}\text { LMR-NCM/ } \\
\text { graphite }\end{array}$} & $\mathrm{C} / 10$ & 229.6 & $99.1 \%$ & 45.4 & 3.7 & 49.1 & $92 \%$ \\
\hline & $\mathrm{C} / 2$ & 214.5 & $92.6 \%$ & 63.5 & 16.2 & 79.7 & $80 \%$ \\
\hline & $1 \mathrm{C}$ & 193.5 & $83.5 \%$ & 66.2 & 30.7 & 96.9 & $68 \%$ \\
\hline & $2 \mathrm{C}$ & 164.1 & $70.8 \%$ & 63.3 & 53.3 & 116.6 & $54 \%$ \\
\hline & $3 C$ & 124.2 & $53.6 \%$ & 39.0 & 77.5 & 116.5 & $33 \%$ \\
\hline \multirow{5}{*}{$\begin{array}{l}\text { NCA/ } \\
\text { graphite }\end{array}$} & $\mathrm{C} / 10$ & 181.3 & $99.1 \%$ & 3.1 & 0.8 & 3.9 & $79 \%$ \\
\hline & $\mathrm{C} / 2$ & 174.1 & $95.2 \%$ & 11.9 & 2.9 & 14.8 & $80 \%$ \\
\hline & $1 \mathrm{C}$ & 166.7 & $91.1 \%$ & 20.7 & 6.8 & 27.5 & $75 \%$ \\
\hline & $2 \mathrm{C}$ & 138.6 & $75.8 \%$ & 26.5 & 17.5 & 44.0 & $60 \%$ \\
\hline & $3 \mathrm{C}$ & 106.1 & $58.0 \%$ & 20.1 & 28.2 & 48.3 & $42 \%$ \\
\hline
\end{tabular}


convective surface cooling and one with a base plate cooling of prismatic cells.

Heat generation.-The heat generation of the LMR-NCM/ graphite and NCA/graphite coin cells was measured for different charge and discharge $\mathrm{C}$-rates using isothermal calorimetry. To verify the reproducibility of the measurements, two cells of each chemistry were measured, the comparison is displayed in Fig. A.1 in the Appendix.

In the following, the measurement results of one cell of each chemistry were further analyzed. The charge and discharge capacities and the accumulated heat in each cycle are listed in Table VI, the normalized heat generation is displayed in Fig. 5. In Table VI, the $\triangle \mathrm{SOC}$ values are referenced to the charge capacity in the $\mathrm{C} / 10$ cycle of each cell. This gives an overview of the capacity throughput in each cycle, which strongly affects the energy that is released as waste heat. The integrated heat was split into the heat during the $\mathrm{CC}$ procedure $\left(Q_{C C}\right)$, and the heat that was measured in the $30 \mathrm{~min}$ pause $\left(Q_{\text {pause }}\right)$ after the current was switched off. For low currents, most of the total heat $\left(Q_{\text {total }}\right)$ was accumulated in the CC phase, indicated by the ratio $Q_{C C} / Q_{\text {total }}$ in the last column of Table VI. With increasing currents, a larger part of this heat was shifted into the pause owing to the time-delayed measurement in the calorimeter. As an example, the $\mathrm{C} / 10$ discharges lasted for over $9 \mathrm{~h}$ while the $3 \mathrm{C}$ discharges only lasted for about $10 \mathrm{~min}$. In Fig. 5, the heat generation is displayed during the $\mathrm{CC}$ phases and the 30 min pauses afterwards. The vertical gray lines mark the time when the current in the $\mathrm{CC}$ phase was switched off. For most charging operations, the maximum heat generation was located slightly after the end of the $\mathrm{CC}$ phase. For the discharge operations, the maximum shifted further to the right with rising C-rates, caused by higher gradients of the heat generation curves at the end of discharge. These time-dependent heat generation profiles from Fig. 5 were used as a model input for the simulations, which were then carried out for each operation until the end of the pause in order to ensure that the maximum cell temperature is captured.

The total heat generation can be split into an irreversible and a reversible part, in which the reversible heat (entropy) is described by the temperature dependence of the open circuit voltage. ${ }^{62-64}$ For low charge/discharge currents, the irreversible heat caused by joule

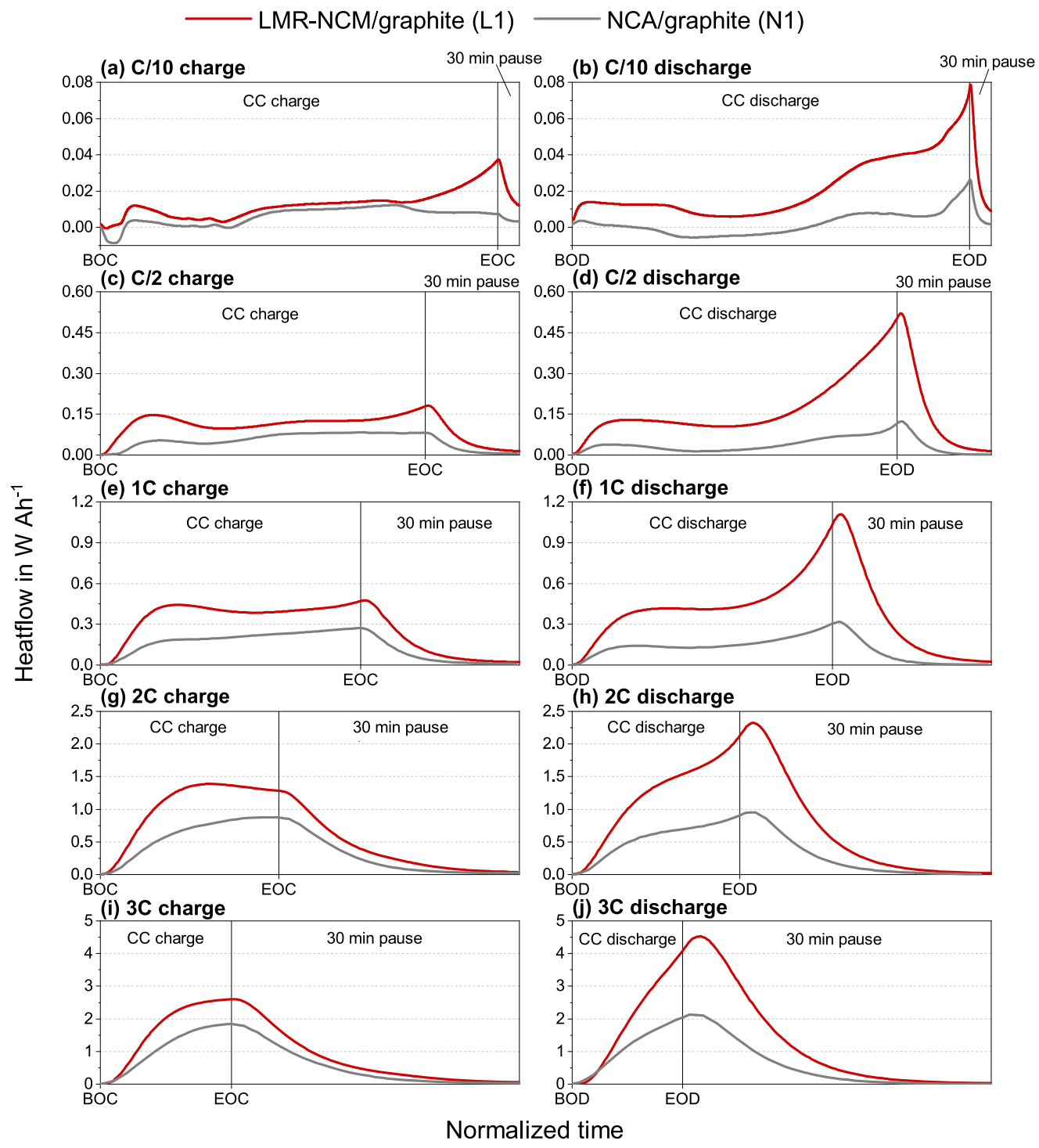

Figure 5. Heat generation of the LMR-NCM/graphite coin cell (L1) and the NCA/graphite coin cell (N1) for varying charge and discharge C-rates including the $30 \mathrm{~min}$ pause afterwards. The heat generation was normalized to the respective charged/discharged capacity in each cycle, and the $x$-axis was normalized to the charging/discharging time. The begin of charge (BOC) represents a SOC of $0 \%$, the begin of discharge (BOD) represents a SOC of $100 \%$, and the respective end of charge (EOC) and end of discharge (EOD) mark the time when the current in the CC phase was switched off. 
heating and reaction overpotentials is likewise low and the contribution of the reversible heat to the total heat is more significant. ${ }^{64}$ This can be seen in Figs. 5a and 5b, where the entropy of the graphite anode is evident. During lithiation of graphite, which is the case in charging operations of full cells, the entropy changes from a positive to a negative sign, ${ }^{14,65-67}$ leading to a cooling down of the cell at the very beginning, e.g., clearly visible for the $\mathrm{C} / 10$ charge of the NCA/graphite cell in Fig. 5a. In comparison to the entropy change of graphite anodes, the entropy difference of NCM and NCA cathodes is less pronounced. ${ }^{14,68,69}$ In our heat flow measurements of full cells, the features caused by an entropy change during the $C / 10$ charge/discharge operations are similar for both cell chemistries. With rising currents, the irreversible heat dominates the heat evolution and the entropy features become less distinct.

The NCA/graphite cells released more heat during charging operations than discharging operations, as shown in Table VI. Manikandan et al. ${ }^{64}$ investigated $18650 \mathrm{NCA} /$ graphite cells and showed that during discharge operations, the sum of the reversible heat is negative and thereby the total heat generation is lowered. However, the LMR-NCM/graphite cells showed quite the opposite behavior releasing more heat during discharge operations, as seen in Table VI. Poor charge transfer kinetics and/or a slow solid-state diffusion together with the OCV hysteresis of LMR-NCM cause the pronounced heat generation that is more dominant during discharge operations. ${ }^{17,28,29}$ An additional SOC dependent resistance of LMRNCM causes the strong temperature increase at the end of the discharges. ${ }^{17}$ As the LMR-NCM OCV hysteresis is presumably current-independent, the increasing irreversible energy loss for rising $\mathrm{C}$-rates is dominated by overpotentials. Figure 5 revealed, that for the same charge or discharge C-rate, the LMR-NCM/graphite cells released much more heat than the NCA/graphite cells, which is clearly caused by the LMR-NCM cathode material, as both cell types contained comparable graphite anodes.

Simulation studies.-The heat generation in the previous Section was determined with coin cells with a nominal capacity of $4.5 \mathrm{mAh}$ (LMR-NCM/graphite) and $3.9 \mathrm{mAh}$ (NCA/graphite), which was scaled to the reference pouch cells with 6.8 Ah (LMR-NCM/ graphite) and 6.3 Ah (NCA/graphite) via the CAM mass of the cells and used as an input parameter for the thermal validation model. In this case, a scaling via the CAM mass was more reliable than a scaling via the electrode area, as the total CAM mass of the pouch cells was known, and the electrode thicknesses of the pouch cells were slightly different.

The comparison of the measured surface temperatures during the discharge rate capability test and the simulated surface temperatures of the pouch cells is displayed in Fig. 6. The measured temperatures were plotted until the end of discharge, as the discharge was immediately followed by a charging procedure. During these measurements, the maximum temperature occurred directly at the end of discharge without a time delay. The simulations used the heat generation displayed in Fig. 5 including the pauses, which is why the simulated temperatures were not plotted until the end of the pause but until the maximum surface temperature was reached in each cycle. The time when the current was switched off in the simulations is marked with a cross in Fig. 6. As the heat measurements in the calorimeter exhibited a time delay, especially affecting higher $\mathrm{C}$-rates, the maximum temperatures of the simulations appeared in the pause after the current was switched off.

For low currents, the simulation results of the LMR-NCM/ graphite cells are in good agreement with the measured surface temperatures of the pouch cells. With increasing discharge C-rates, the deviation $\left|\Delta T_{\mathrm{dev} \text {,max }}\right|$ also increases. Up to and including the $1 \mathrm{C}$ discharge, the absolute deviations remain below $2 \mathrm{~K}$, which is acceptable for our simulation purposes considering that the precision of the temperature sensor used in the pouch cell measurements was $\pm 1 \mathrm{~K}$. However, at the end of the $2 \mathrm{C}$ discharge, the deviation is
$6.2 \mathrm{~K}$, and for a $3 \mathrm{C}$ discharge the deviation doubles to $12.7 \mathrm{~K}$. While the heat generation measurements of the coin cells in the calorimeter were performed under isothermal conditions at $25^{\circ} \mathrm{C}$ and then scaled up, the temperature of the pouch cells increased during operation. In general, lithium-ion batteries are very temperature-sensitive, with a higher operating temperature, the transport and kinetics enhance, the internal cell resistance decreases and more capacity can be discharged from the cell. ${ }^{70-72}$ For a 1C discharge, the LMR-NCM/ graphite coin cells delivered around $84 \%$ of their C/10 capacity, $71 \%$ for a $2 \mathrm{C}$ discharge, and only $54 \%$ for a $3 \mathrm{C}$ discharge. In comparison, during the rate capability test, the $6.8 \mathrm{Ah}$ LMR-NCM/graphite pouch cells delivered around $93 \%$ for a $1 \mathrm{C}$ discharge, $88 \%$ for a $2 \mathrm{C}$ discharge, and $77 \%$ for a $3 \mathrm{C}$ discharge. ${ }^{24}$ The longer the cells can sustain a certain $\mathrm{C}$-rate, more capacity can be discharged from the cell and more heat will be released during this process, resulting in higher cell temperatures. Up to a discharge C-rate of $1 \mathrm{C}$, the homogenized thermal model can adequately represent the behavior of the modeled LMR-NCM/graphite pouch cells. For this reason, the subsequent simulation studies with varying cooling conditions were only carried out for discharge rates of $\mathrm{C} / 10, \mathrm{C} / 2$, and $1 \mathrm{C}$.

Comparing the NCA/graphite simulation results, a similar trend can be observed. With rising discharge C-rates, the temperature deviation also becomes higher. However, the maximum deviation is lower, e.g., $1.7 \mathrm{~K}$ for the $3 \mathrm{C}$ discharge, because the NCA/graphite pouch cells exhibited a less pronounced temperature increase, making the measured coin cell heat generation more comparable to the one in the larger pouch cells. In the $\mathrm{C} / 10$ discharge simulation, the cell temperature decreases from a starting temperature of $26.5^{\circ} \mathrm{C}$ down to $25^{\circ} \mathrm{C}$ while the measured temperature stayed almost constant. This discrepancy with a maximum deviation of $1.5 \mathrm{~K}$ can be explained with possible inhomogeneous thermal conditions during the experiment. In the simulation model, the temperatures of the cell and the adjacent aluminum blocks were set to the same value, while the experimental temperature conditions may have been different between the pouch cell and the cell holder. The $\mathrm{C} / 10$ discharge of the pouch cells was carried out directly after a $\mathrm{C} / 10$ CCCV charging operation with no pause in between, resulting in inhomogeneous thermal starting conditions. The aim of the following simulation studies with the homogenized thermal 3D model was a qualitative assessment of maximum temperatures that occur in larger cell formats, so a deviation below $2 \mathrm{~K}$ was considered as acceptable.

The cell holder of the pouch cells consisted of two aluminum blocks, which represent an additional heat sink for the generated heat in the cell. Waldmann et al. ${ }^{73}$ experimentally investigated the temperatures and temperature gradients of different pouch and cylindric lithium-ion cells and, among other things, used an aluminum block with an $18 \mathrm{~mm}$ hole including mounted dissipaters and fans for cooling of an 18650 cylindric cell. With this setup, they could drastically reduce the cell temperature during operation. Even if the aluminum blocks of the pouch cell holder were not actively cooled, the cell temperatures without this additional heat sink would certainly be higher.

Convective cooling. - In our first study, thermal simulations with convective cooling boundary conditions for the cell formats listed in Table IV were carried out. In contrast to the preceding model validation, no cell holder or respective aluminum blocks were added to the model. Only the jelly roll or electrode stack and the corresponding cell case were modeled, and the whole surface of the housing was exposed to a convective heat flow. In this way, a general comparison between all cell formats was possible, independent of the cooling conditions of a specific application. Furthermore, the heat generation was scaled via the total electrode area of the cathode that fits into each cell format, not via the amount of active material. The maximum temperatures of the cell formats for discharge $\mathrm{C}$-rates of $\mathrm{C} / 10, \mathrm{C} / 2$, and $1 \mathrm{C}$ are displayed in 


\section{LMR-NCM/graphite —Measurement} - - - Simulation
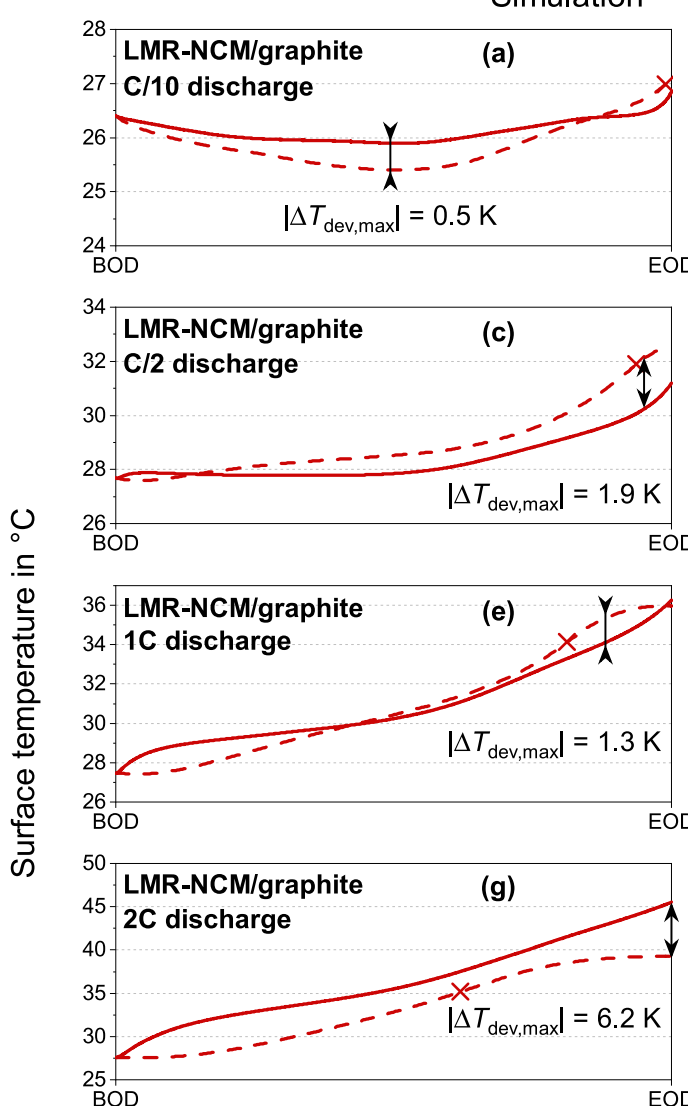

EOD BOD

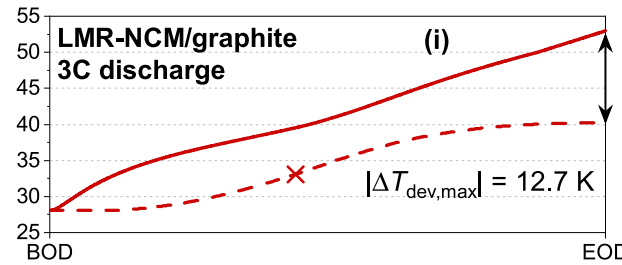

EOD $B O$
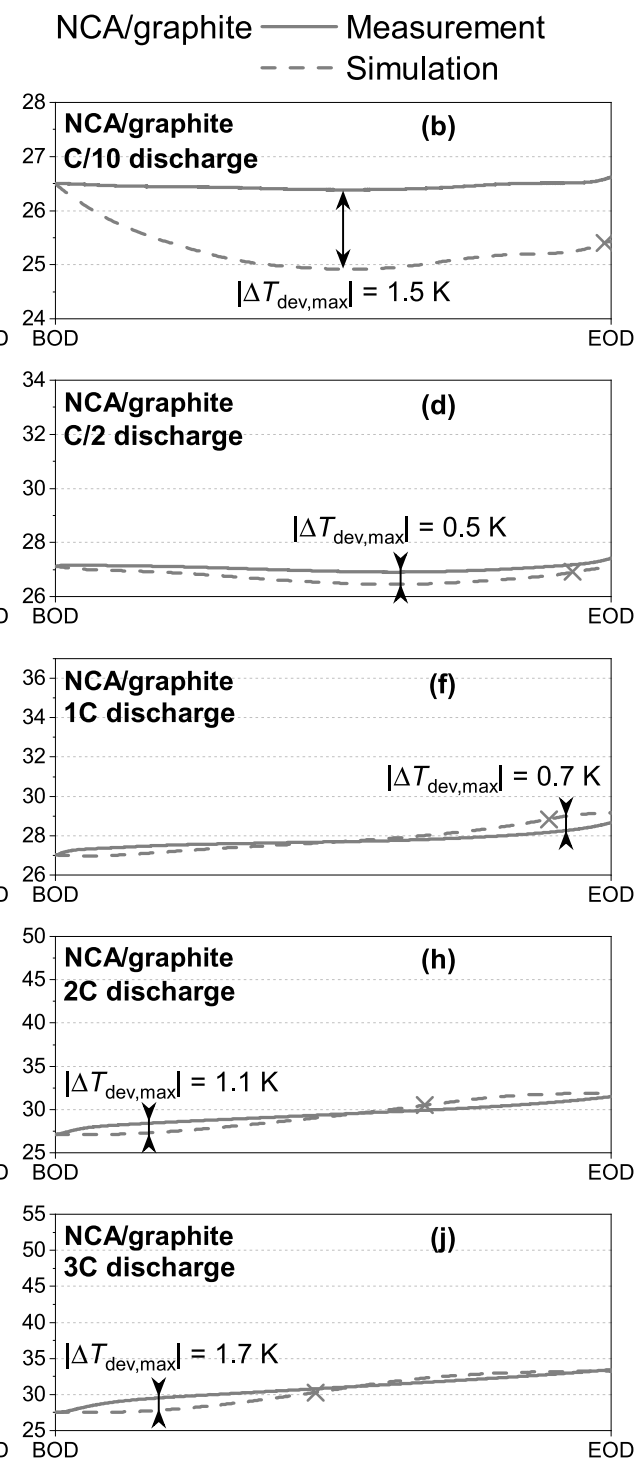

Normalized time

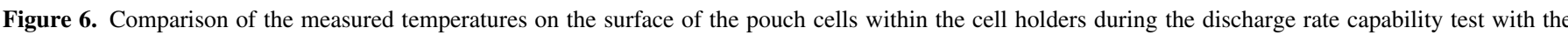

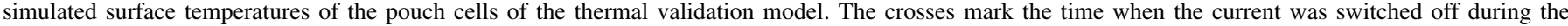
simulation. For each C-rate, the maximum deviation $\left|\Delta T_{\mathrm{dev}, \max }\right|$ is indicated with the black arrow.

Fig. 7. The filled symbols indicate the LMR-NCM/graphite cells, while the open symbols indicate the NCA/graphite cells. As the cells were uniformly cooled via the whole surface of the case, the maximum temperatures occurred in the core of the jelly roll or electrode stack.

In Fig. 7a, a natural convection of $5 \mathrm{~W} \mathrm{~m}^{-2} \mathrm{~K}^{-1}$ on the surface of the cells was simulated, meaning that the cells were not actively cooled during operation; the heat is passively dissipated from the cell surface to the surrounding air. If cells are cooled via their surface, the decisive parameter is the surface to volume $(\mathrm{S} / \mathrm{V})$ ratio, as listed in Table IV. The higher the S/V ratio for a constant cell volume, the more cooling surface is available and the lower the cell temperatures become. For the pouch and prismatic cell formats, the HEV cells have the highest $\mathrm{S} / \mathrm{V}$ ratio and the $\mathrm{BEV}$ cells the lowest ratio, with the PHEV cells somewhere in between, resulting in maximum temperatures $T_{\max , \mathrm{HEV}}<T_{\max , \mathrm{PHEV}}<T_{\max , \mathrm{BEV}}$ for convective cooling. The $\mathrm{S} / \mathrm{V}$ ratio of cylindrical cells decreases with increasing cell diameter, hence $T_{\max , 18650}<T_{\max , 21700}<T_{\max , 26650}$. The nominal cell capacity plays a minor role, e.g., during a $1 \mathrm{C}$ discharge under natural convection $\left(5 \mathrm{~W} \mathrm{~m}^{-2} \mathrm{~K}^{-1}\right)$, the maximum temperatures of the cylindric $26650 \mathrm{LMR}-\mathrm{NCM} /$ graphite cell with $5.5 \mathrm{Ah}$ are similar to the PHEV2 LMR-NCM/graphite pouch cell with $66 \mathrm{Ah}$.

For a $\mathrm{C} / 10$ discharge, with a heat transfer coefficient of $5 \mathrm{~W} \mathrm{~m}^{-2} \mathrm{~K}^{-1}$ in Fig. 7a, all LMR-NCM/graphite cells reach temperatures above $31^{\circ} \mathrm{C}$ up to $42{ }^{\circ} \mathrm{C}$, while the NCA/graphite cells only heat up to $28^{\circ} \mathrm{C}$. For the $\mathrm{C} / 2$ and $1 \mathrm{C}$ discharges, the temperatures of the LMR-NCM/graphite cells drastically increase, most cell formats reaching critical temperatures above $60^{\circ} \mathrm{C}$, whereas the NCA/graphite cell temperatures stay below $50^{\circ} \mathrm{C}$. The thermal model was not validated for the simulated cell formats, but the differentiation of the maximum temperatures between the LMR-NCM/graphite and the NCA/graphite cells becomes obvious.

In the study of Waldmann et al., ${ }^{73}$ a commercial 18650 high energy $\mathrm{NCA} /$ graphite cell with $3.25 \mathrm{Ah}$ reached temperatures between $32-43{ }^{\circ} \mathrm{C}$ for discharges with $\mathrm{C} / 10, \mathrm{C} / 2$, and $1 \mathrm{C}$ at an ambient temperature of $25^{\circ} \mathrm{C}$, which is about the temperature range of our simulations for cylindric NCA/graphite cells. Furthermore, they stated, that the maximum cell temperatures depend linearly on the discharge $\mathrm{C}$-rate for a full discharge. ${ }^{73} \mathrm{~A}$ rescaling of the $x$-axis in Fig. 7 shows, that the temperature correlation for the three investigated discharge C-rates is not perfectly linear, however, with 


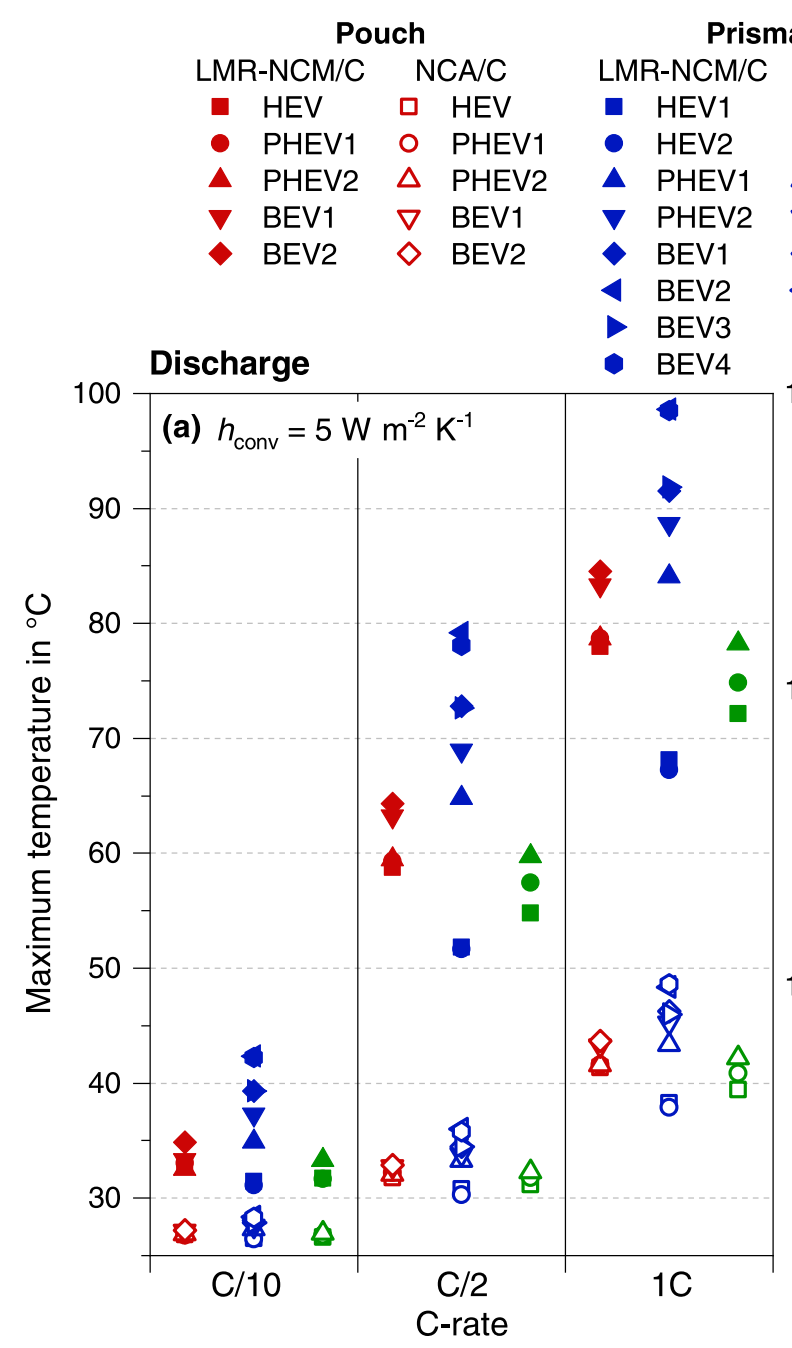

Prismatic

NCA/C

HEV1

O HEV2

$\triangle$ PHEV1

$\nabla$ PHEV2

$\diamond$ BEV1

$\triangleleft$ BEV2

$\triangle$ BEV3

- BEV4

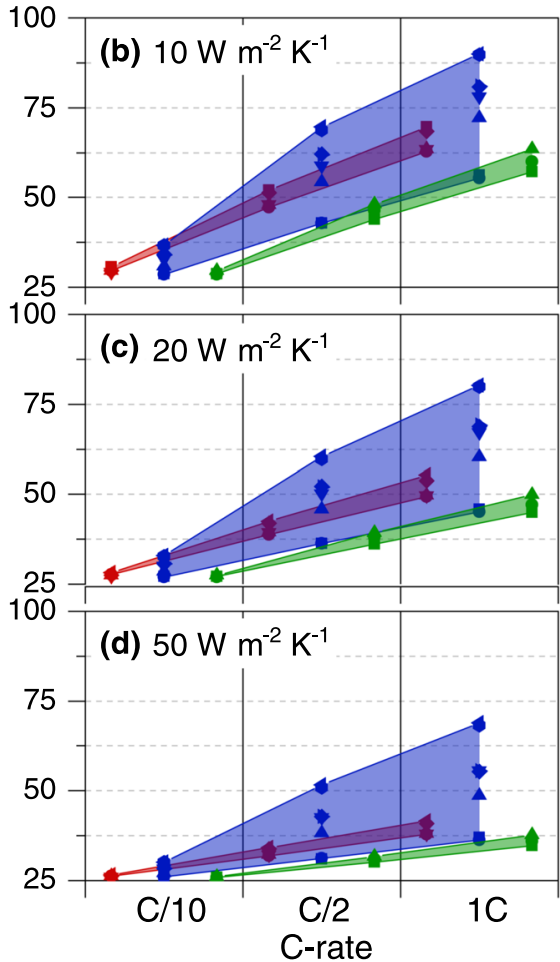

Figure 7. Simulated maximum temperatures of LMR-NCM/graphite and NCA/graphite chemistries in different cell formats (stated in Table IV) during or after discharge processes with a convective surface cooling scenario of (a) $h_{\text {conv }}=5 \mathrm{~W} \mathrm{~m}^{-2} \mathrm{~K}^{-1}$, (b) $10 \mathrm{~W} \mathrm{~m}^{-2} \mathrm{~K}^{-1}$, (c) $20 \mathrm{~W} \mathrm{~m}^{-2} \mathrm{~K}^{-1}$, and (d) $50 \mathrm{~W} \mathrm{~m} \mathrm{~K}^{-1}$. In (b), (c), and (d) only the LMR-NCM/graphite cells are shown, and the colored areas indicate the temperature range of the respective cell format. The starting temperature of the cells as well as the ambient temperature were set to $25^{\circ} \mathrm{C}$.

this assumption, one could still estimate the maximum temperatures that are reached with higher $\mathrm{C}$-rates for a given cell format.

In this work, the NCA/graphite cells were used as a state-of-theart reference, but the focus is on the thermal behavior of the LMR$\mathrm{NCM} /$ graphite cells, so in the following studies, only the latter are further analyzed. If a higher surface cooling is assumed, as $10 \mathrm{~W} \mathrm{~m}^{-2} \mathrm{~K}^{-1}$ seen in Fig. $7 \mathrm{~b}, 20 \mathrm{~W} \mathrm{~m}^{-2} \mathrm{~K}^{-1}$ in Fig. $7 \mathrm{c}$, and $50 \mathrm{~W} \mathrm{~m}^{-2} \mathrm{~K}^{-1}$ in Fig. 7d, the pouch (red area) and cylindric (green area) LMR-NCM/graphite cell formats can be kept within acceptable temperature ranges. The prismatic cells show quite a diverging behavior and four sub-groups with a similar $\mathrm{S} / \mathrm{V}$ ratio can be identified. The first group consists of the HEV1 (15 Ah) and HEV2 (14 Ah) cells that are comparatively thin with a thickness of $12.5 \mathrm{~mm}$ and $12.1 \mathrm{~mm}$ and a $\mathrm{S} / \mathrm{V}$ ratio of $2.6 \mathrm{~m}^{-1}$ and $2.7 \mathrm{~m}^{-1}$, respectively. The PHEV1 cell with a nominal capacity of $41 \mathrm{Ah}$, a thickness of $21 \mathrm{~mm}$, and a $\mathrm{S} / \mathrm{V}$ ratio of $1.6 \mathrm{~m}^{-1}$ forms the second group. The third group consists of the PHEV2 (48 Ah, $26.5 \mathrm{~mm}$, $\left.1.3 \mathrm{~m}^{-1}\right)$, the BEV1 $\left(90 \mathrm{Ah}, 32 \mathrm{~mm}, 1.1 \mathrm{~m}^{-1}\right.$ ), and the BEV3 (98 Ah, $32 \mathrm{~mm}, 1.0 \mathrm{~m}^{-1}$ ) cells. The BEV2 (127 Ah, $45 \mathrm{~mm}$, $0.8 \mathrm{~m}^{-1}$ ) and BEV4 (139 Ah, $45 \mathrm{~mm}, 0.8 \mathrm{~m}^{-1}$ ) cells form the fourth group. Even with a heat transfer coefficient of $50 \mathrm{~W} \mathrm{~m}^{-2} \mathrm{~K}^{-1}$, the thick BEV2 and BEV4 formats reach maximum temperatures around $68^{\circ} \mathrm{C}$ for a $1 \mathrm{C}$ discharge.

Within this first simulation study it became clear that the cell format plays a crucial role for the temperature evolution of large-format LMR-NCM/graphite cells. Without any active cooling, either the discharge should be limited to $\mathrm{C}$-rates lower than $\mathrm{C} / 2$, or thinner cell formats with a comparatively high $\mathrm{S} / \mathrm{V}$ ratio and a low nominal capacity like the prismatic HEV1/HEV2 or the cylindric 18650 are favorable. By using an active cooling system, larger cell formats and higher discharge C-rates are possible, however very thick cells with a high capacity like the BEV2 and BEV4 cells cannot be sufficiently convectively cooled via their surface ${ }^{74}$ and reach critical temperatures. Therefore, in the next section, a more adapted cooling strategy for prismatic cells is described.

Base plate cooling.-In our second study, a bottom plate cooling of prismatic cell formats was simulated. Large-format prismatic cells are used by car manufacturers in EVs to reach high energy densities and sufficient driving ranges. An active thermal management of the battery pack is often realized via cooled plates that are mounted underneath the cells. Therefore, the bottom of the prismatic cell case was kept at a constant temperature of $20^{\circ} \mathrm{C}$ during the simulations. To have homogeneous starting conditions, the cell temperature was also set to $20^{\circ} \mathrm{C}$. The simulation results for a $1 \mathrm{C}$ discharge of four different prismatic LMR-NCM/graphite cells are shown in Fig. 8. In the previous convective simulations, four sub-groups of prismatic cells were identified based on their different thermal behavior. For this study, one representative of each group, namely the HEV2, PHEV1, BEV1, and BEV2 cell formats were chosen. 


\section{LMR-NCM/graphite 1C discharge}
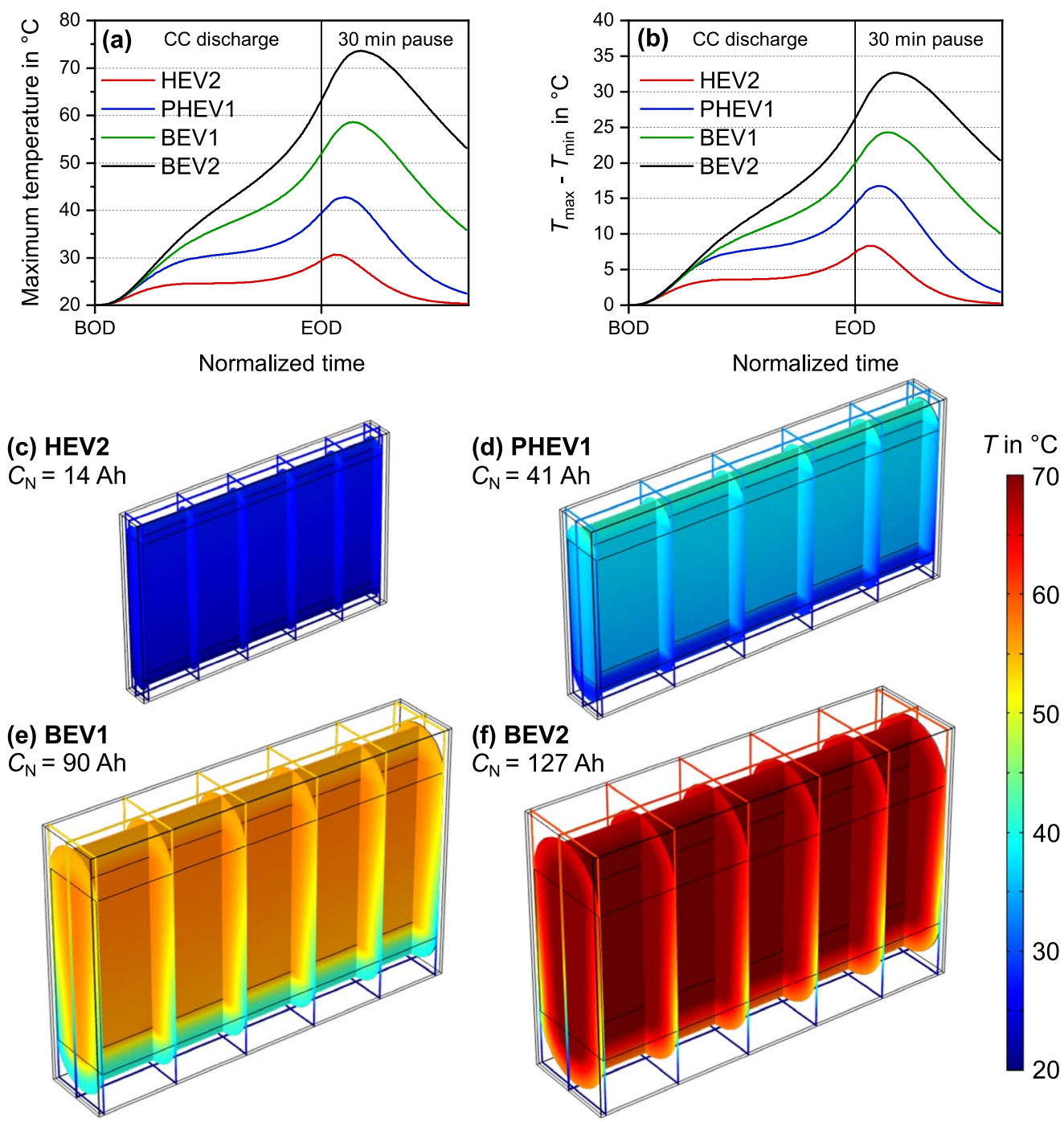

Figure 8. Simulated temperatures during a $1 \mathrm{C}$ discharge and the $30 \mathrm{~min}$ pause afterwards with a base plate cooling scenario of prismatic LMR-NCM/graphite cells. (a) Maximum temperature and (b) temperature spread $\left(T_{\max }-T_{\min }\right)$ within the jelly roll. The 3D plots show the temperatures of the cell formats (c) HEV2, (d) PHEV1, (e) BEV1, and (f) BEV2 at the time, when the maximum cell temperature was reached. The starting temperature of the cells as well as the constant temperature of the base plate were set to $20^{\circ} \mathrm{C}$.

In Fig. 8a, the maximum temperatures of the four cell formats within the jelly roll during the $1 \mathrm{C}$ discharge and the $30 \mathrm{~min}$ pause afterwards are shown. Particularly at the end of discharge, the temperatures drastically rise, as the heat generation of the LMRNCM/graphite cells increases rapidly, as seen in Fig. 5. Because of the time-delayed measurement of the heat generation, the maximum temperatures occurred after the end of discharge. In Fig. 8b, the temperature spread within the jelly roll is displayed. The higher this temperature spread is within the cell, the more inhomogeneities there will be. This results in uneven internal resistances, loads, and SOCs during cycling and most likely also a different aging behavior. ${ }^{73,75}$ Furthermore, usually there are no internal temperature sensors in the cells, so with high temperature gradients, a battery management system has more difficulties to track or estimate the hottest temperature within the cell to prevent safety critical conditions. For all these reason, if possible, the temperature spread within a cell should be kept minimal.

In Figs. 8c-8f, 3D temperature distributions of the four cell formats are plotted at the exact time, when the maximum jelly roll temperature was reached (i.e., at the time of the maximum in Fig. 8a). In the simulations of the base plate cooling of prismatic cells, the coldest temperature was always at the bottom of the cell, as this is where the cooling plate was attached. On the other hand, the hottest temperature was at the top of the cell, as this is the furthest away from the cooling side, and the top and side areas were thermally insulated, derived by the neighboring cells in a module and the electrical connection on the top.

With the base plate cooling strategy, the four cell formats still exhibit distinct differences in their thermal behavior, the maximum temperatures are around $10{ }^{\circ} \mathrm{C}$ higher for the next larger cell. If full discharge cycles are necessary, the HEV2 (representing also HEV1) and PHEV1 cell formats are advantageous, as their maximum temperatures stay below $43{ }^{\circ} \mathrm{C}$. The BEV2 cell reaches $74{ }^{\circ} \mathrm{C}$ at its hottest spot, however, if the $1 \mathrm{C}$ discharge would be stopped after e.g., $80 \%$ of the time, the maximum temperature would be much lower. For our simulations, the cooling plate was kept at a constant temperature of $20^{\circ} \mathrm{C}$. With a better thermal management system and a higher cooling power, this temperature could be lowered, yet the temperature spread within the cell would also increase. ${ }^{73,75}$ There is a spread of more than $30^{\circ} \mathrm{C}$ within the BEV2 cell already, so this strategy might not be helpful.

A tab cooling system could provide a better and more homogeneous cooling, especially for pouch cells. ${ }^{74}$ Thus, not only the 
cooling strategy has to be adapted to the cell format, but also the load profile of the corresponding application. A dynamic load profile around a mean SOC could result in a quite different temperature evolution. In summary, an application defines the specific requirements of the preferred cell format and the design of the corresponding thermal management system.

\section{Conclusions}

In this work, the heat generation of LMR-NCM/graphite cells was investigated. The LMR-NCM cathode active material comes with a pronounced difference between charge and discharge voltage during operation, caused by overpotentials and an OCV hysteresis. This voltage difference results in an energy inefficiency that is released as waste heat and causes a strong heat generation. As a reference, an established NCA/graphite material combination was chosen. So far, LMR-NCM was predominantly studied in small laboratory-scale cells where the heat generation is negligible. However, in large-format LMR-NCM/graphite cells, critical temperatures above $60{ }^{\circ} \mathrm{C}$ can easily be reached. In order to qualitatively assess the thermal behavior of large-format cells, the heat generation of LMR-NCM/graphite and NCA/graphite coin cells was measured in a heat flow calorimeter, scaled to various standardized cell formats via their electrode area, and used as an input parameter for homogenized 3D thermal models.

The calorimetric measurements showed, that during charging operations, the LMR-NCM/graphite cells generate more than double the heat than comparable NCA/graphite cells. During discharge operations, the LMR-NCM/graphite cells released even more heat, making it four times more than the NCA/graphite cells. The coin cells used for the calorimetry stayed quasi-isothermal during these measurements, whereas larger cells heat up during operation. The model validation with measurement data from reference 6-7 Ah pouch cells showed, that for the LMR-NCM/graphite cells, the upscaling of the heat generation is only valid up to $1 \mathrm{C}$, as higher cell temperatures resulted in a promoted electrochemical behavior that is not accounted for in this process. For the same C-rate, the LMR$\mathrm{NCM} /$ graphite cells generate more heat during discharge operations than charge operations. Therefore, only the thermal behavior during discharge operations was further investigated in two simulation studies.

In our first simulation study, a convective cooling scenario for standardized prismatic, pouch, and cylindric cell formats for discharge rates of $\mathrm{C} / 10, \mathrm{C} / 2$, and $1 \mathrm{C}$ was analyzed. With only passive cooling, i.e., natural convection on the surface of the cells, either the discharge current has to be limited to C-rates lower than $\mathrm{C} / 2$, or thin cell formats with a high surface to volume ratio and comparatively low nominal capacity are favorable. Good examples are the prismatic HEV1 and HEV2 cells as well as the cylindric 18650 cell. By using an active convective cooling strategy, more heat can be dissipated and most cell formats show acceptable temperature ranges. Exceptions are posed by thick prismatic cell formats, e.g., the BEV2 and BEV4 cells, that cannot be sufficiently cooled via convection. Even with a forced convection, simulated with a heat transfer coefficient of $50 \mathrm{~W} \mathrm{~m}{ }^{-2} \mathrm{~K}^{-1}$, maximum temperatures of these two cell formats of around $68^{\circ} \mathrm{C}$ were reached for a $1 \mathrm{C}$ discharge.

In our second study, a base plate cooling of four prismatic cell formats during a $1 \mathrm{C}$ discharge was simulated. This cooling strategy is more adapted to automotive prismatic cell formats as often used in EVs. With this base plate cooling, the HEV1, HEV2, and PHEV1 cell formats were advantageous, as the cell temperatures remained below $43{ }^{\circ} \mathrm{C}$. The thicker prismatic cells reached higher temperatures between $58^{\circ} \mathrm{C}-74^{\circ} \mathrm{C}$, accompanied by an unfavorable temperature spread within the jelly roll of more than $32{ }^{\circ} \mathrm{C}$ from the coldest spot on the bottom to the hottest spot on the top. In the simulations, only full discharge cycles were considered, whereas with partial discharges or dynamic load profiles around a mean SOC, the thermal behavior of the cells would certainly be different.

To summarize, the thermal behavior of cells containing LMRNCM should be accounted for. Especially larger cell formats and higher charge/discharge currents can result in undesired cell temperatures. This heat generation is mainly caused by the voltage difference between charge and discharge of LMR-NCM, so the thermal behavior of materials with a similarly lower voltage efficiency should also be carefully investigated. Silicon, for example, exhibits a pronounced voltage difference of $\approx 300 \mathrm{mV}$ between charge and discharge even at low currents. ${ }^{76}$ The aim of our work was to highlight the general implications of the heat generation caused by an active material like LMR-NCM with a low voltage efficiency on the thermal behavior of different cell formats. For a specific application, including its corresponding load profile, an optimal cell design and operating strategy for the thermal management system could be derived.

\section{Acknowledgments}

This work was financially supported by the German Federal Ministry of Education and Research (BMBF) under grant number 03XP0255 (ExZellTUM III). The authors gratefully acknowledge the scientific discussions with Johannes Sturm and Franziska Friedrich, and thank BASF SE for the supply of cathode materials.

\section{Appendix}

In the results section in Fig. 5, the heat generation of one LMR$\mathrm{NCM} /$ graphite and one NCA/graphite coin cell was shown. In order to validate that these cells provide meaningful values, the heat generation of a second coin cell of each type was measured in the calorimeter. In Fig. A.1, the comparison of the heat generation for two cells each during charge and discharge was plotted for the $\mathrm{C}$ rates $\mathrm{C} / 10, \mathrm{C} / 2$, and $1 \mathrm{C}$. The heat generation rates of the two LMR$\mathrm{NCM} /$ graphite cells are in excellent agreement, the two NCA/ graphite cells differ slightly. Therefore, the higher heat generation of cell N1 was chosen for the simulations.

The input parameters of the homogenized jelly roll/electrode stack for the thermal model were calculated based on the material properties of multilayer LMR-NCM/graphite pouch cells. ${ }^{24,27}$ The

Table A I. Calculation of the thermal modeling parameters of the homogenized jelly roll/electrode stack based on multilayer LMR-NCM/graphite pouch cells. $^{24,27}$ The material properties were taken from data sheets and literature. ${ }^{14,31,51}$

\begin{tabular}{|c|c|c|c|c|c|c|c|}
\hline Parameter & Unit & $\begin{array}{c}\mathrm{CC}_{\text {neg }} \\
\mathrm{Cu}\end{array}$ & $\begin{array}{c}\text { Coating }_{\text {neg }} \\
\text { graphite }\end{array}$ & $\begin{array}{c}\text { Separator } \\
\text { PP }\end{array}$ & $\begin{array}{l}\text { Coating }_{\text {pos }} \\
\text { LMR-NCM }\end{array}$ & $\begin{array}{c}\mathrm{CC}_{\text {pos }} \\
\mathrm{Al}\end{array}$ & Electrolyte \\
\hline$l$ & $\mu \mathrm{m}$ & 12 & 64 & 25 & 55 & 15 & \\
\hline porosity & $\%$ & & 30 & 55 & 42 & & \\
\hline$\rho$ & $\mathrm{kg} \mathrm{m}^{-3}$ & 8920 & 2208 & 980 & 3960 & 2698 & 1289 \\
\hline$c_{\mathrm{p}}$ & $\mathrm{J} \mathrm{kg}^{-1} \mathrm{~K}^{-1}$ & 385 & 867 & 1978 & 840 & 903 & 2055 \\
\hline$k$ & $\mathrm{~W} \mathrm{~m}{ }^{-1} \mathrm{~K}^{-1}$ & 398 & 1.04 & 0.33 & 1.58 & 238 & 0.6 \\
\hline
\end{tabular}

Note. CC—current collector, PP—polypropylene. 
(a) Charge LMR-NCM/graphite

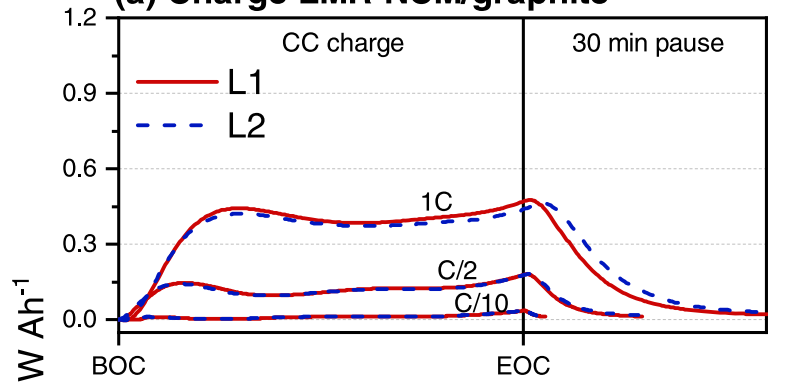

(c) Charge NCAgraphite

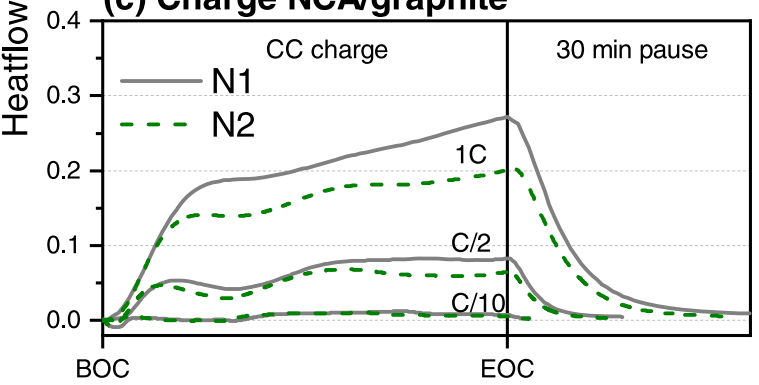

(b) Discharge LMR-NCM/graphite

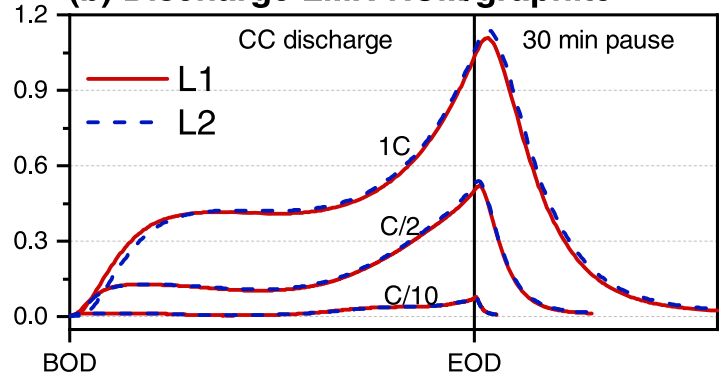

(d) Discharge NCAVgraphite

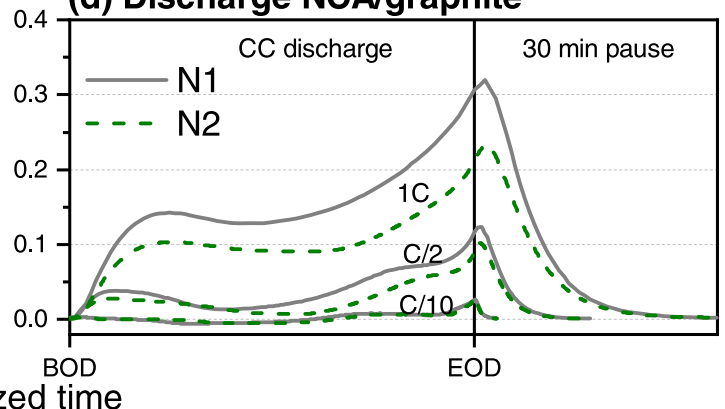

Figure A·1. Comparison of the heat generation of two LMR-NCM/graphite coin cells and two NCA/graphite coin cells for varying charge and discharge C-rates including the $30 \mathrm{~min}$ pause afterwards. The heat generation was normalized to the respective charge/discharge capacity in each cycle, and the $x$-axis was normalized to the charge/discharge time. The begin of charge (BOC) represents a SOC of 0\%, the begin of discharge (BOD) represents a SOC of 100\%, while the respective end of charge (EOC) and end of discharge (EOD) mark the time when the current in the CC phase was switched off.

following equations calculate the total density $\rho_{\text {tot }}$, the heat capacity $c_{\mathrm{p} \text {,tot }}$, the through-plane thermal conductivity $k_{\perp}$, and the in-plane thermal conductivity $k_{\|}$based on the respective layer thicknesses $l^{14,31,47}$ The corresponding material properties are listed in Table A.I.

$$
\begin{aligned}
& \rho_{\text {tot }}=\frac{\sum_{\mathrm{i}} \rho_{\mathrm{i}} l_{\mathrm{i}}}{l_{\text {tot }}}=2427 \mathrm{~kg} \mathrm{~m}^{-3} \\
& c_{\mathrm{p}, \text { tot }}=\frac{\sum_{\mathrm{i}} \rho_{\mathrm{i}} c_{\mathrm{p}, \mathrm{i}} l_{\mathrm{i}}}{\rho_{\mathrm{tot}} l_{\mathrm{tot}}}=1049 \mathrm{~J} \mathrm{~kg}^{-1} \mathrm{~K}^{-1} \\
& k_{\perp}=\frac{l_{\text {tot }}}{\sum_{\mathrm{i}} \frac{l_{\mathrm{i}}}{k_{\mathrm{i}}}}=0.83 \mathrm{~W} \mathrm{~m}^{-1} \mathrm{~K}^{-1} \\
& k_{\|}=\frac{\sum_{\mathrm{i}} l_{\mathrm{i}} k_{\mathrm{i}}}{l_{\text {tot }}}=27.3 \mathrm{~W} \mathrm{~m}^{-1} \mathrm{~K}^{-1}
\end{aligned}
$$

\section{ORCID}

Ludwig Kraft (D) https://orcid.org/0000-0003-4324-426X Tanja Zünd (DD https://orcid.org/0000-0002-1650-3636 Alexander Kunz (iD https://orcid.org/0000-0003-3169-4263 Marco Steinhardt (iD https://orcid.org/0000-0003-1356-1686 Andreas Jossen (iD https://orcid.org/0000-0003-0964-1405

\section{References}

1. D. Andre, S.-J. Kim, P. Lamp, S. F. Lux, F. Maglia, O. Paschos, and B. Stiaszny, "Future generations of cathode materials: An automotive industry perspective." Journal of Materials Chemistry A, 3, 6709 (2015).

2. R. E. Ciez and J. F. Whitacre, "Comparison between cylindrical and prismatic lithium-ion cell costs using a process based cost model." Journal of Power Sources, 340, 273 (2017).
3. R. Schmuch, R. Wagner, G. Hörpel, T. Placke, and M. Winter, "Performance and cost of materials for lithium-based rechargeable automotive batteries." Nat. Energy, 3, 267 (2018)

4. Y. Ding, Z. P. Cano, A. Yu, J. Lu, and Z. Chen, "Automotive Li-Ion Batteries: Current Status and Future Perspectives." Electrochemical Energy Reviews, 2, (2019).

5. G. Offer, Y. Patel, A. Hales, L. Bravo Diaz, and M. Marzook, "Cool metric for lithium-ion batteries could spur progress." Nature, 582, 485 (2020).

6. T. G. Tranter, R. Timms, P. R. Shearing, and D. J. L. Brett "Communication-Prediction of Thermal Issues for Larger Format 4680 Cylindrical Cells and Their Mitigation with Enhanced Current Collection." J. Electrochem. Soc., 167, 160544 (2020).

7. M. Armand, P. Axmann, D. Bresser, M. Copley, K. Edström, C. Ekberg, D. Guyomard B. Lestriez, P. Novák, M. Petranikova, W. Porcher, S. Trabesinger, M. WohlfahrtMehrens, and H. Zhang, "Lithium-ion batteries - Current state of the art and anticipated developments." Journal of Power Sources, 479, 228708 (2002).

8. J. B. Quinn, T. Waldmann, K. Richter, M. Kasper, and M. Wohlfahrt-Mehrens, "Energy Density of Cylindrical Li-Ion Cells: A Comparison of Commercial 18650 to the 21700 Cells." J. Electrochem. Soc., 165, A3284 (2018).

9. DIN Deutsches Institut für Normung e.V., Electrically propelled road vehiclesBattery systems-Design specifications for Lithium-Ion battery cells (2016-11).

10. G. E. Blomgren, "The Development and Future of Lithium Ion Batteries." J. Electrochem. Soc., 164, A5019 (2016).

11. T.-F. Yi, L.-J. Jiang, J. Shu, C.-B. Yue, R.-S. Zhu, and H.-B. Qiao, "Recent development and application of $\mathrm{Li}_{4} \mathrm{Ti}_{5} \mathrm{O}_{12}$ as anode material of lithium ion battery." J. Phys. Chem. Solids, 71, 1236 (2010).

12. W.-J. Zhang, "A review of the electrochemical performance of alloy anodes for lithium-ion batteries." Journal of Power Sources, 196, 13 (2011).

13. Z. Luo, D. Fan, X. Liu, H. Mao, C. Yao, and Z. Deng, "High performance silicon carbon composite anode materials for lithium ion batteries." Journal of Power Sources, 189, 16 (2009)

14. J. Sturm, A. Rheinfeld, I. Zilberman, F. B. Spingler, S. Kosch, F. Frie, and A. Jossen, "Modeling and simulation of inhomogeneities in a 18650 nickel-rich, silicon-graphite lithium-ion cell during fast charging." Journal of Power Sources, 412, 204 (2019).

15. E. Moyassari, L. Streck, N. Paul, M. Trunk, R. Neagu, C.-C. Chang, S.-C. Hou, B. Märkisch, R. Gilles, and A. Jossen, "Impact of Silicon Content within SiliconGraphite Anodes on Performance and Li Concentration Profiles of Li-Ion Cells using Neutron Depth Profiling." J. Electrochem. Soc., 168, 020519 (2021).

16. J. R. Croy, M. Balasubramanian, K. G. Gallagher, and A. K. Burrell, "Review of the U.S. Department of Energy's "deep dive" effort to understand voltage fade in Liand Mn-rich cathodes." Acc. Chem. Res., 48, 2813 (2015).

17. T. Teufl, D. Pritzl, S. Solchenbach, H. A. Gasteiger, and M. A. Mendez, "State of Charge Dependent Resistance Build-Up in Li- and Mn-Rich Layered Oxides during Lithium Extraction and Insertion.” J. Electrochem. Soc., 166, A1275 (2019). 
18. D. Becker, M. Börner, A. Friesen, S. Klein, U. Rodehorst, M. Diehl, M. Winter, T. Placke, and R. Schmuch, "Towards High-Performance Li-rich NCM-Graphite Cells by Germanium-Polymer Coating of the Positive Electrode Material.' J. Electrochem. Soc., 167, 060524 (2020).

19. J. Helbig, T. Beuse, V. Siozios, T. Placke, M. Winter, and R. Schmuch, "Li-MnRich Cathode Materials with Low-Cobalt Content and Core-Shell Particle Design for High-Energy Lithium Ion Batteries.” J. Electrochem. Soc., 167, 060519 (2020).

20. G. Assat, S. L. Glazier, C. Delacourt, and J.-M. Tarascon, "Probing the thermal effects of voltage hysteresis in anionic redox-based lithium-rich cathodes using isothermal calorimetry." Nat. Energy, 4, 647 (2019).

21. N. Leifer, T. Penki, R. Nanda, J. Grinblat, S. Luski, D. Aurbach, and G. Goobes, "Linking structure to performance of $\mathrm{Li}_{1.2} \mathrm{Mn}_{0.54} \mathrm{Ni}_{0.13} \mathrm{Co}_{0.13} \mathrm{O}_{2}$ ( $\mathrm{Li}$ and $\mathrm{Mn}$ rich NMC) cathode materials synthesized by different methods." Physical chemistry chemical physics : PCCP, 22, 9098 .

22. J. R. Croy, K. G. Gallagher, M. Balasubramanian, B. R. Long, and M. M. Thackeray, "Quantifying Hysteresis and Voltage Fade in $\mathrm{xLi}_{2} \mathrm{MnO}_{3} \cdot(1-\mathrm{x}) \mathrm{LiMn}_{0.5} \mathrm{Ni}_{0.5} \mathrm{O}_{2}$ Electrodes as a Function of $\mathrm{Li}_{2} \mathrm{MnO}_{3}$ Content." J. Electrochem. Soc., 161, A318 (2014).

23. D. Mohanty, J. Li, D. P. Abraham, A. Huq, E. A. Payzant, D. L. Wood, and C. Daniel, "Unraveling the Voltage-Fade Mechanism in High-Energy-Density Lithium-Ion Batteries: Origin of the Tetrahedral Cations for Spinel Conversion." Chemistry of Materials, 26, 6272 (2014).

24. L. Kraft, T. Zünd, D. Schreiner, R. Wilhelm, F. J. Günter, G. Reinhart, H. A. Gasteiger, and A. Jossen, "Comparative Evaluation of LMR-NCM and NCA Cathode Active Materials in Multilayer Lithium-Ion Pouch Cells: Part II. Rate Capability, Long-Term Stability, and Thermal Behavior." J. Electrochem. Soc., 168, 020537 (2021).

25. F. Wu, J. Maier, and Y. Yu, "Guidelines and trends for next-generation rechargeable lithium and lithium-ion batteries." Chem. Soc. Rev., 49, 1569 (2020).

26. P. Meister, H. Jia, J. Li, R. Kloepsch, M. Winter, and T. Placke, "Best Practice Performance and Cost Evaluation of Lithium Ion Battery Active Materials with Special Emphasis on Energy Efficiency." Chemistry of Materials, 28, 7203 (2016)

27. D. Schreiner, T. Zünd, F. J. Günter, L. Kraft, B. Stumper, F. Linsenmann, M. Schüßler, R. Wilhelm, A. Jossen, G. Reinhart, and H. A. Gasteiger, "Comparative Evaluation of LMR-NCM and NCA Cathode Active Materials in Multilayer Lithium-Ion Pouch Cells: Part I. Production, Electrode Characterization, and Formation." J. Electrochem. Soc., 168, 030507 (2021).

28. J. Zheng, W. Shi, M. Gu, J. Xiao, P. Zuo, C. Wang, and J.-G. Zhang, "Electrochemical Kinetics and Performance of Layered Composite Cathode Material $\mathrm{Li}\left[\mathrm{Li}_{0.2} \mathrm{Ni}_{0.2} \mathrm{Mn}_{0.6}\right] \mathrm{O}_{2}$." J. Electrochem. Soc., 160, A2212 (2013).

29. W. Mao, G. Ai, Y. Dai, Y. Fu, X. Song, H. Lopez, and V. Battaglia, "Nature of the Impedance at Low States of Charge for High-Capacity, Lithium and ManganeseRich Cathode Materials." J. Electrochem. Soc., 163, A3091 (2016).

30. J. R. Croy, K. G. Gallagher, M. Balasubramanian, Z. Chen, Y. Ren, D. Kim, S.H. Kang, D. W. Dees, and M. M. Thackeray, "Examining Hysteresis in Composite $\mathrm{xLi}_{2} \mathrm{MnO}_{3} \cdot(1-\mathrm{x}) \mathrm{LiMO}_{2}$ Cathode Structures." The Journal of Physical Chemistry C, 117, 6525 (2013)

31. S. C. Chen, C. C. Wan, and Y. Y. Wang, "Thermal analysis of lithium-ion batteries." Journal of Power Sources, 140, 111 (2005).

32. G.-H. Kim, K. Smith, K.-J. Lee, S. Santhanagopalan, and A. Pesaran, "MultiDomain Modeling of Lithium-Ion Batteries Encompassing Multi-Physics in Varied Length Scales." J. Electrochem. Soc., 158, A955 (2011).

33. S. V. Erhard, P. J. Osswald, J. Wilhelm, H. E. Hoster, and A. Jossen, "Simulation and Measurement of Local Potentials of Modified Commercial Cylindrical Cells: II: Multi-Dimensional Modeling and Validation." J. Electrochem. Soc., 162, A2707 (2015).

34. A. Rheinfeld, S. Kosch, S. V. Erhard, P. J. Osswald, B. Rieger, and A. Jossen, "Electro-Thermal Modeling of Large Format Lithium-Ion Pouch Cells: A Cel Temperature Dependent Linear Polarization Expression.” J. Electrochem. Soc., 163, A3046 (2016).

35. B. Rieger, S. V. Erhard, S. Kosch, M. Venator, A. Rheinfeld, and A. Jossen, "MultiDimensional Modeling of the Influence of Cell Design on Temperature, Displacement and Stress Inhomogeneity in Large-Format Lithium-Ion Cells." J. Electrochem. Soc., 163, A3099 (2016).

36. D. Chen, J. Jiang, G.-H. Kim, C. Yang, and A. Pesaran, "Comparison of different cooling methods for lithium ion battery cells." Applied Thermal Engineering, 94 846 (2016)

37. H. Lundgren, P. Svens, H. Ekström, C. Tengstedt, J. Lindström, M. Behm, and G. Lindbergh, "Thermal Management of Large-Format Prismatic Lithium-Ion Battery in PHEV Application.” J. Electrochem. Soc., 163, A309 (2016).

38. R. Kantharaj and A. M. Marconnet, "Heat Generation and Thermal Transport in Lithium-Ion Batteries: A Scale-Bridging Perspective." Nanoscale and Microscale Thermophysical Engineering, 23, 128 (2019).

39. J. Sturm, A. Frank, A. Rheinfeld, S. V. Erhard, and A. Jossen, "Impact of Electrode and Cell Design on Fast Charging Capabilities of Cylindrical Lithium-Ion Batteries." J. Electrochem. Soc., 167, 130505 (2020).

40. H. Park, "A design of air flow configuration for cooling lithium ion battery in hybrid electric vehicles." Journal of Power Sources, 239, 30 (2013).

41. J. Zhao, Z. Rao, and Y. Li, "Thermal performance of mini-channel liquid cooled cylinder based battery thermal management for cylindrical lithium-ion power battery." Energy Conversion and Management, 103, 157 (2015).

42. A. de Vita, A. Maheshwari, M. Destro, M. Santarelli, and M. Carello, "Transient thermal analysis of a lithium-ion battery pack comparing different cooling solutions for automotive applications." Applied Energy, 206, 101 (2017).
43. K.-H. Chen, M. J. Namkoong, V. Goel, C. Yang, S. Kazemiabnavi, S. M. Mortuza, E. Kazyak, J. Mazumder, K. Thornton, J. Sakamoto, and N. P. Dasgupta, "Efficien fast-charging of lithium-ion batteries enabled by laser-patterned three-dimensional graphite anode architectures." Journal of Power Sources, 471, 228475 (2020).

44. G. Reinhart, T. Zeilinger, J. Kurfer, M. Westermeier, C. Thiemann, M. Glonegger M. Wunderer, C. Tammer, M. Schweier, and M. Heinz, "Research and Demonstration Center for the Production of Large-Area Lithium-Ion Cells." Future Trends in Production Engineering, ed. G. Schuh, R. Neugebauer, and E. Uhlmann (Springer, Berlin, Heidelberg) 3 (2013).

45. R. Schröder, M. Aydemir, and G. Seliger, "Comparatively Assessing different Shapes of Lithium-ion Battery Cells." Procedia Manufacturing, 8, 104 (2017).

46. A. Kwade, W. Haselrieder, R. Leithoff, A. Modlinger, F. Dietrich, and K. Droeder, "Current status and challenges for automotive battery production technologies." Nat. Energy, 3, 290 (2018).

47. T. M. Bandhauer, S. Garimella, and T. F. Fuller, "A Critical Review of Thermal Issues in Lithium-Ion Batteries.” J. Electrochem. Soc., 158, R1 (2011).

48. H. Maleki, S. A. Hallaj, J. R. Selman, R. B. Dinwiddie, and H. Wang, "Therma Properties of Lithium-Ion Battery and Components.” J. Electrochem. Soc., 146, 947 (1999).

49. K. Darcovich, D. D. MacNeil, S. Recoskie, and B. Kenney, "Coupled electrochemical and thermal battery models for thermal management of prismatic automotive cells." Applied Thermal Engineering, 133, 566 (2018).

50. M. Steinhardt, E. I. Gillich, M. Stiegler, and A. Jossen, "Thermal conductivity inside prismatic lithium-ion cells with dependencies on temperature and external compression pressure." Journal of Energy Storage, 32, 101680 (2020).

51. S. D. Lubner, S. Kaur, Y. Fu, V. Battaglia, and R. S. Prasher, "Identification and characterization of the dominant thermal resistance in lithium-ion batteries using operando 3-omega sensors." J. Appl. Phys., 127, 105104 (2020).

52. T. Bandhauer, S. Garimella, and T. F. Fuller, "Electrochemical-Thermal Modeling to Evaluate Battery Thermal Management Strategies: I. Side Cooling." J. Electrochem. Soc., 162, A125 (2015).

53. X. Zhang and T. Wierzbicki, "Characterization of plasticity and fracture of shell casing of lithium-ion cylindrical battery." Journal of Power Sources, 280, 47 (2015).

54. J. Zhu, X. Zhang, E. Sahraei, and T. Wierzbicki, "Deformation and failure mechanisms of 18650 battery cells under axial compression." Journal of Power Sources, 336, 332 (2016).

55. M. Ikezoe, N. Hirata, C. AMEMIYA, T. Miyamoto, Y. Watanabe, T. Hirai, and T. Sasaki, "Development of High Capacity Lithium- Ion Battery for NISSAN LEAF." SAE International, 2012-01-0664, 1 (2012).

56. M. Keyser, A. Pesaran, Q. Li, S. Santhanagopalan, K. Smith, E. Wood, S. Ahmed I. Bloom, E. Dufek, M. Shirk, A. Meintz, C. Kreuzer, C. Michelbacher, A. Burnham, T. Stephens, J. Francfort, B. Carlson, J. Zhang, R. Vijayagopal, K. Hardy, F. Dias, M. Mohanpurkar, D. Scoffield, A. N. Jansen, T. Tanim, and A. Markel, "Enabling fast charging-Battery thermal considerations." Journal of Power Sources, 367, 228 (2017).

57. D. T. Adams, G. Berdichevsky, T. E. Colson, A. Hebert, S. Kohn, D. Lyons, N. J. Mendez, J. B. Straubel, D. West, and A. Simpson, Battery Pack Thermal Management System, Patent Application Publication (2009), US 2009/0023056A1.

58. J. Kim, J. Oh, and H. Lee, "Review on battery thermal management system for electric vehicles." Applied Thermal Engineering, 149, 192 (2019).

59. Y. Deng, C. Feng, E. J. H. Zhu, J. Chen, M. Wen, and H. Yin, "Effects of different coolants and cooling strategies on the cooling performance of the power lithium ion battery system: A review." Applied Thermal Engineering, 142, 10 (2018).

60. A. Adam, J. Wandt, E. Knobbe, G. Bauer, and A. Kwade, "Fast-Charging of Automotive Lithium-Ion Cells: In-Situ Lithium-Plating Detection and Comparison of Different Cell Designs." J. Electrochem. Soc., 167, 130503 (2020).

61. X. Feng, X. He, M. Ouyang, L. Lu, P. Wu, C. Kulp, and S. Prasser, "Thermal runaway propagation model for designing a safer battery pack with $25 \mathrm{Ah}$ $\mathrm{LiNi}_{\mathrm{x}} \mathrm{Co}_{\mathrm{y}} \mathrm{Mn}_{\mathrm{z}} \mathrm{O}_{2}$ large format lithium ion battery." Applied Energy, 154, 74 (2015).

62. K. Takano, Y. Saito, K. Kanari, K. Nozaki, K. Kato, A. Negishi, and T. Kato "Entropy change in lithium ion cells on charge and discharge." Journal of Applied Electrochemistry, 32, 251 (2002).

63. P. J. Osswald, M. D. Rosario, J. Garche, A. Jossen, and H. E. Hoster, "Fast and Accurate Measurement of Entropy Profiles of Commercial Lithium-Ion Cells.' Electrochimica Acta, 177, 270 (2015).

64. B. Manikandan, C. Yap, and P. Balaya, "Towards Understanding Heat Generation Characteristics of Li-Ion Batteries by Calorimetry, Impedance, and Potentiometry Studies." J. Electrochem. Soc., 164, A2794 (2017).

65. Y. Reynier, R. Yazami, and B. Fultz, "The entropy and enthalpy of lithium intercalation into graphite." Journal of Power Sources, 119-121, 850 (2003).

66. Y. Reynier, J. Graetz, T. Swan-Wood, P. Rez, R. Yazami, and B. Fultz, "Entropy of $\mathrm{Li}$ intercalation in $\mathrm{Li}_{\mathrm{x}} \mathrm{CoO}_{2}$." Physical Review B, 70, 753 (2004).

67. R. Yazami and Y. Reynier, "Thermodynamics and crystal structure anomalies in lithium-intercalated graphite." Journal of Power Sources, 153, 312 (2006).

68. R. E. Williford, V. V. Viswanathan, and J.-G. Zhang, "Effects of entropy changes in anodes and cathodes on the thermal behavior of lithium ion batteries." Journal of Power Sources, 189, 101 (2009).

69. V. V. Viswanathan, D. Choi, D. Wang, W. Xu, S. Towne, R. E. Williford, J.-G. Zhang, J. Liu, and Z. Yang, "Effect of entropy change of lithium intercalation in cathodes and anodes on Li-ion battery thermal management." Journal of Power Sources, 195, 3720 (2010).

70. S. S. Zhang, K. Xu, and T. R. Jow, "Charge and discharge characteristics of a commercial $\mathrm{LiCoO}_{2}$-based $18650 \mathrm{Li}$-ion battery.” Journal of Power Sources, 160, 1403 (2006). 
71. K. Kumaresan, G. Sikha, and R. E. White, "Thermal Model for a Li-Ion Cell." J. Electrochem. Soc., 155, A164 (2008).

72. X.-G. Yang, T. Liu, Y. Gao, S. Ge, Y. Leng, D. Wang, and C.-Y. Wang, "Asymmetric Temperature Modulation for Extreme Fast Charging of Lithium-Ion Batteries." Joule, 3, 3002 (2019).

73. T. Waldmann, G. Bisle, B.-I. Hogg, S. Stumpp, M. A. Danzer, M. Kasper, P. Axmann, and M. Wohlfahrt-Mehrens, "Influence of Cell Design on Temperature and Temperature Gradients in Lithium-Ion Cells: An In Operando Study." J. Electrochem. Soc., 162, A921 (2015).
74. A. Hales, R. Prosser, L. Bravo Diaz, G. White, Y. Patel, and G. Offer, "The Cell Cooling Coefficient as a design tool to optimise thermal management of lithium-ion cells in battery packs." eTransportation, 6, 100089 (2020).

75. C. Veth, D. Dragicevic, and C. Merten, "Thermal characterizations of a largeformat lithium ion cell focused on high current discharges." Journal of Power Sources, 267, 760 (2014).

76. Y. Jiang, G. Offer, J. Jiang, M. Marinescu, and H. Wang, "Voltage Hysteresis Model for Silicon Electrodes for Lithium Ion Batteries, Including Multi-Step Phase Transformations, Crystallization and Amorphization." J. Electrochem. Soc., 167, 130533 (2002). 